\title{
"Truth, Justice and the American Way": The Intersection of American Youth Culture and Superhero Narratives
}

\author{
Sebastian T. Mercier*
}

Youth culture has remained an enigmatic presence in American cultural studies. Many adults struggle to accept "the concept of teenagers as an independent age group." ${ }^{84}$ The volatile nature of teenage fads has lead to the belief in their ultimate disposability. One understudied topic in youth cultural studies is the mainstream superhero comic book. For parents and other adults, comics are conventionally regarded as a medium of childish amusement, unworthy of serious attention. A young Mike Geralds complained in a 1965 Avengers letters column, "no matter how hard I try, my mom and dad won't even look at my AVENGERS, F.F., or SPIDER-MAN." ${ }^{85}$ For their part, high culture critics consistently have "perceived lack of literary or artistic merit" in the study of superheroes and comic books. ${ }^{86}$ Most have regarded superheroes as twodimensional figures designed to appeal to a low culture audience. Only recently have superheroes begun to be accepted as a legitimate area of academic scholarship. $^{87}$

Those who do not take mainstream superheroes seriously fail to take into account the complex process underlying the reading of a comic book, which is commonly known as "comic book literacy." Scott McCloud, one of the foremost comic book theorists, defines comic book literacy as the total interaction of panels, words, pictures, and narrative tropes used by the writer/artist. ${ }^{88}$ Superhero and other genres of comic books have used these literary devices to combine the visual with the textual. The reliance on what McCloud defines as "sequential art" enhances the mythic possibilities of the superhero medium. According to comic book writer Will Eisner, a superhero story must "relate very abstract ideas,

\footnotetext{
*I am most grateful to Professor Colin Gordon for supporting my ideas and providing valuable insights as my thesis advisor. Professors Jeffrey Cox, Jacki Rand, and Kathleen Kamerick were invaluable sources of stability and advice. My first comic book was X-Men (vol. 2) \#2. Since that time, superheroes have always held a special place in my heart. The works of Stan "The Man" Lee, Will Eisner, Jack “King” Kirby, Frank Miller, Dennis O’Neill, Neal Adams, and many more inspired my research endeavors. Lastly, I am indebted to my parents who never lost faith in me and encouraged me to be an independent thinker.

${ }^{84}$ Grace Palladino, Teenagers: An American History (New York: Basic Books, 1996), xiii.

${ }^{85}$ Stan Lee et al., The Avengers \#13 (New York: Marvel Comics, 1965), 24.

${ }^{86}$ Amy Kiste Nyberg, Seal of Approval: The History of the Comics Code (Jackson: University Press of Mississippi, 1998), 4.

${ }^{87}$ Geoff Klock's How to Read Superhero Comics and Why, Bradford Wright's Comic Book Nation, and the works of the historian Les Daniels have sought to treat superheroes as a topic worthy of academic inquiry

${ }^{88}$ Scott McCloud, Understanding Comics: The Invisible Art (New York: Kitchen Sink Press, 1993), 193.
} 
science, or unfamiliar concepts by the analogous use of familiar forms or phenomena." ${ }^{\text {}}$ Over the years, superhero comic books have subtly interwoven the realities of historical events and political trends in the guise of heroic fable. Superheroes have survived because of their continuing social relevance and ability to evolve with the times. Underneath the supervillain battles and colorful costumes are a rich tapestry of cultural history that reflects American society. Superheroes have battled real-world figures including Adolf Hitler, tackled controversial topics such as racism, and provoked discussions of cultural shifts within America.

This paper examines the mainstream superhero industry as it evolved from the 1930s into the 1980s. An examination of superheroes, even from the earliest comic books, shows that they played an important role in reflecting contemporary American values and concerns. Superhero history can be divided into two distinct eras. The Golden Age saw the superhero archetype being developed under the legacy of the Great Depression and the specter of World War II. By the end of the Golden Age, the superhero industry was reeling from societal charges that the comic book industry was feeding juvenile delinquency. The Silver Age saw a resurgence of the superhero, led by Stan Lee and Marvel Comics. This era ushered in new ideas and new business practices. The superhero began to evolve from its simpler roots and became more complex in outlook. By the end of the 1980s, the superhero industry had taken on a decidedly mature tone and attitude. Despite dramatic change both within and outside the comic book industry, superheroes have remained a part of the American consciousness ever since their creation.

Even into present times, widely promoted storylines such as Marvel's “Civil War” and DC's “Infinite Crisis" have garnered media attention. These events have appealed to both long-time readers and a new youth infusion that has embraced comic books using alternative media avenues such as superhero movies and cartoons. The study of superheroes and their conventions must be an essential part of any popular culture historical narrative. Superheroes provide a link to the past, a snapshot of the present, and a window into the future of American society.

\section{Superhero Origins and the Wartime Experience}

Superheroes first emerged on the national scene in the 1930s, in the context of the Great Depression. The earliest superheroes confronted corporate malfeasance. The exploits of Superman, the Spirit, and others were closely aligned to President Franklin D. Roosevelt's New Deal. These superheroes were morally pure and incapable of corruptive influences. The economic realities of the 1930s also favored the rise of superhero comic books. With wages down and enthusiasm low, many teenagers needed a low-cost leisure pursuit they could enjoy. Newspaper comic strips did not provoke the typical teenager's fantastical imagination. Movie productions were still relatively crude. Radio was an important medium -- in 1938, Orson Welles' rendition of The War of the Worlds

${ }^{89}$ Will Eisner, Graphic Storytelling and Visual Narrative (Tamarac: Poorhouse Press, 1996), 11. 
was so moving that it convinced many of its listeners of an actual alien invasion ${ }^{90}$. Pulp serials of heroes such as the Shadow were more popular in their radio incarnations. The comic book medium would seize on the opportunity to create a new market. They would provide cheap thrills, daring exploits, and vivid depictions of the fantastic. Unlike its predecessors, the comic book would seize on the youth market's thirst for an identifiable cultural icon.

The first major superhero icon, Superman, came out of this imaginative tradition. Artist Joe Shuster and writer Jerry Siegel were at a major professional crossroads in 1938. For several years, they had been seeking to break into the newspaper funnies section with an obscure superhero dubbed Superman. The only problem was that the Great Depression had severely undermined start-up strips. The specter of losing money on an unknown quantity such as Superman was considered to be a risky business venture. Shuster and Siegel became so discouraged that they began to seek other print media for their Superman pitch. ${ }^{91}$

At the same time, National Allied Publications (now Detective Comics) were looking for a new angle in which to promote their monthly brand of comic books. Companies such as National Allied were able to take chances that newspapers could not: the cost of producing a quickly drawn comic strip was cheap in contrast to a newspaper, which had to commit valuable time and money for a yearly strip. National Allied became intrigued by the idea behind Superman. Siegel and Shuster reciprocated their interest. Action Comics \#1, featuring Superman on the cover, debuted in June 1938 to little fanfare and promotion. The thematic elements (including Superman's origin) were derived from old pulp magazine serials such as Tarzan and John Carter of the Planet Mars. ${ }^{92}$ These characters had made the successful transition to the storytelling style of comic books and had achieved a moderate level of profit for publishing houses.

Superman has been an American popular culture symbol ever since. His continued popularity over the years can be attributed to his strong principles and faith in American democracy. Superman embodied the American ethos of the "everyman" while remaining a fantastic figure in his own right. The persona of his alter-ego, Clark Kent, was simple and modest. Kent had been adopted by a hardworking middle-class Kansas farming couple. In the minds of many Americans, agriculture still strongly embodied the American spirit. ${ }^{93}$ Youth could look to Superman as a role model. His principles were larger than himself. One couldn't fly or have X-Ray vision, but one certainly could espouse the attitude of Superman.

Superman promoted the middle-class segment of American society. He fought against all who would deny the average person their inalienable rights as democratic citizens. Superman's popularity resulted from his folklore status in an "industrial society," 94 from his willingness to protect traditional agrarian values in

${ }^{90}$ Edward J. Ruppelt, The Report on Unidentified Flying Objects (Chicago: Source Books \& Sacred Spaces, 2003), 58.

${ }^{91}$ M. Thomas Inge, Comics as Culture (Jackson: University Press of Mississippi, 1990), 140.

${ }^{92}$ Ron Goulart, The Encyclopedia of American Comics (New York: Facts on File, 1990), 334.

${ }^{93}$ Warren I. Susman, Culture as History: The Transformation of American Society in the Twentieth Century (Washington D.C.: Smithsonian Institution Press, 2003), 33.

${ }^{94}$ M. Thomas Inge, Comics as Culture (Jackson: University Press of Mississippi, 1990), 141. 
an urban setting. He is an outsider who needs to be a superhero to curb the urban vices of "crime, poverty, alienation, and totalitarianism."95 Many of the earliest Superman tales show a preoccupation with protecting the middle class of American society.

In this sense, Superman echoed the contemporary "New Deal" administration of Franklin D. Roosevelt, which sought to protect the middle class from the unregulated impulses of a free-market economy. Roosevelt's New Deal defined itself against what it considered the social ills of American society. The New Deal was largely credited with preventing a domestic revolution in American society. Roosevelt's gradual definition of the New Deal was centered on the belief that the capitalist system could be effectively regulated by an active government. Roosevelt stated, "I am not for a return to that definition of liberty under which for many years a free people were gradually regimented into the service" of corporate monopolies. ${ }^{96}$ The domestic programs set up by Roosevelt and his New Deal coalition helped many Americans regain a new sense of hope for the future of their country. However, the powerful attitude of a shared national experience that was promoted by Roosevelt must be shared with popular culture formats such as comic books. ${ }^{97}$

Such themes emerge again and again in the early Superman comics. Many of the earliest Superman tales focused on protection of the middle class segments of mainstream American society. Superman's maxim was to be "a champion of the oppressed...to devote his existence to those in need!"98 In Superman \#2, Superman investigates a case where a rival business CEO tries to murder a union of workers in order to get a profitable contract. The metal cage which the business tycoon sets up for protection is smashed easily by Superman. ${ }^{99}$ He literally breaks through the protective capacities of monopolies. Superman shows that the political climate of 1930s America drastically changed in the span of a few short years.

Comic book superheroes such as Superman echoed New Deal principles so much that they became borderline promoters of FDR's ideology. Superman portrayed the "federal government as the common man's benefactor" against an environment where "organized crime....infiltrated labor unions." ${ }^{100}$ The common man had to be protected through political reform, according to New Deal rhetoric. Rising labor militancy would lead to a widely feared social revolution. The fear of a widespread revolt maintained its relevance because of the long-held American belief in isolating itself from European developments. Comic book superheroes accepted the fears of New Deal politicians by promoting cultural morality standards which would help to stabilize American society.

\footnotetext{
${ }^{95}$ Ibid., 142.

${ }^{96}$ Alan Brinkley, The End of Reform: New Deal Liberalism in Recession and War (New York: Vintage Books, 1995), 10.

${ }^{97}$ Bradford W. Wright, Comic Book Nation: The Transformation of Youth Culture in America (Baltimore: Johns Hopkins University Press, 2001), 11.

${ }_{98}^{9}$ Jerry Siegel and Joe Shuster, Superman Archives Vol. 1 (New York: DC Comics, 1989), 10.

${ }^{99}$ Ibid., 132-34.

${ }^{100}$ Wright, Comic Book Nation, 26.
} 
Another influential superhero of the era was the Spirit, created in 1940 by a young comic book entrepreneur named Will Eisner. Along with Superman, the Spirit was credited with starting the superhero revolution in comic books. The Spirit was originally conceived by Eisner as an avenging detective who solved crimes that the normal police could not solve. Eisner did not consciously set out to create a superhero figure. Rather, he was pressured to put a bright blue mask on the Spirit due to an insatiable demand for caped vigilantes. ${ }^{101}$ Eisner believed that the comic book medium was vastly underutilized as a genuine American art form. He wanted to get away from the formulaic superhero tales that had been popular ever since Superman debuted in 1938. Comic book scholar Jules Feiffer recalled:

Eisner's line had weight. Clothing sat on his characters heavily; when they bent an arm, deep folds sprang into action everywhere. When one Eisner character slugged another, a real fist hit real flesh. Violence was no externalized plot exercise, it was the gut of his style. Massive and indigestible, it curdled, lava-like, from the page. ${ }^{102}$

Eisner saw a glaring contradiction inherent in the emerging superhero titles: superheroes were champions of American progress but had little use for the emerging innovations of the 1930s. Skyscrapers, trains, and guns were all destroyed by superheroes. Eisner answered the contradiction by theorizing that superheroes inhabited a middle ground for American progress. They were the protectors of a middle class who "found their opportunities for personal freedom curtailed by the realities of mass market capitalism."103 The immediacy of Eisner's art style recalled the fast-paced transformations of American politics under the guise of the New Deal. His popularity among young readers is due to the fact that the Spirit was a middle-class everyman looking out for a good living.

In the meantime, Superman continued to embody different aspects of 1930s American culture. Clark Kent's job as a reporter for the Daily Planet places him in positions which test his dedication to the male gender roles of patriarchal responsibility. For example, in Superman \#1, Kent is challenged by a rival male suitor for Lane's affections. After, his refusal to meet the suitor's challenge in physical confrontation, Lane huffs that Kent is a "spineless unbearable coward!" 104 The culture of the 1930s emphasized the man as a "family wage" protector. The example in Superman \#1 is emblematic of what social critic William Whyte called the feminization of the male gender role. Conformity to the middle-class conception of success implied that Kent was being

\footnotetext{
${ }^{101}$ Stanley Wiater and Stephen R. Bisette, Comic Book Rebels: Conversations with the Creators of the New Comics (New York: Donald I. Fine, Inc., 1993), 275.

102 Jules Feiffer, The Great Comic Book Heroes (New York: Dial Press, 1965), 33.

${ }^{103}$ Aldo Regalado, “Modernity, Race, and the American Superhero," in Comics as Philosophy, ed. Jeff McLaughlin (Jackson: University Press of Mississippi, 2005), 84.

${ }^{104}$ Jerry Siegel and Joe Shuster, Superman Archives Vol. 1 (New York: DC Comics, 1989), 20.
} 
institutionalized by the power of the majority. ${ }^{105}$ Some men saw individuality and personal expression being lost as a part of fitting into the workplace. In contrast, the persona of Superman is a manifestation of non-conformist impulses. His costume is rich in color and design, in stark contrast to Kent's drab gray suit. Furthermore, Lois Lane is clearly attracted to the manly and aggressive nature espoused by Superman. Superman \#3 showed Lane intentionally drugging Kent so she can fulfill her "distant, charmed” longings for Superman. ${ }^{106}$

Gender politics remained a contentious issue during the 1930s. The reformist impulses of the New Deal, in the real world and in the comics, had its limits. On the eve of Roosevelt's first term as President, New Dealers avoided gender politics because of the "great damage" the culture wars of the 1920s had done to the Democratic Party. ${ }^{107}$ Traditional gender roles persisted in the progressive reform society of the era. Superman's love interest, Lois Lane, represented an idealized femininity for Superman's readers. The overwhelming idealization of young marriage made the competition for a spouse a cutthroat endeavor. College women saw a social environment where campus enrollments eventually stood between "75 percent to 90 percent women" because of the demands placed on male enlistment for World War II. ${ }^{108}$ A woman such as Lane who willingly chose the workforce over a life of household chores and childrearing was deemed "selfish...and deeply disapproved."109 Gender role expectations were an important plot device in the earliest Superman tales.

Depictions of race also reflected the times despite concerted efforts by several comic book writers. Will Eisner was praised for regularly including African-American characters in his Spirit tales. Nevertheless, these characters were heavily stereotyped. "Introducing Silk Satin” (1941) featured the Spirit's sidekick, Ebony White. His very name is a racial pun which reinforced racial preconceptions. Furthermore, his broken English shows his dim-witted nature. Ebony White's appearance is also shockingly racially stereotyped. A typical panel shows him with a wide, angular face with huge eyelids and prominent red lips. ${ }^{110}$ Eisner's willingness to include African-Americans in his Spirit tales showed his rebel mentality. Over time, the more racist qualities of Ebony White would evolve into a complex character. Despite many racial stereotypes, Ebony White was an enduring and charming character. Ebony White's presence in a mainstream American comic book broke the norm and introduced the concept of racial diversity to young readers.

The Spirit highlighted the divisions that were inherent in American youth culture. There were no morality lessons in Spirit tales. The Spirit was not

\footnotetext{
${ }^{105}$ William H. Whyte, The Organization Man (Philadelphia: University of Pennsylvania Press, 2002), 59.

${ }^{106}$ Jerry Siegel and Joe Shuster, Superman Archives Vol. 1 (New York: DC Comics, 1989), 186.

${ }^{107}$ Alan Brinkley, The End of Reform: New Deal Liberalism in Recession and War (New York: Vintage Books, 1995), 9.

${ }^{108}$ Beth L. Bailey, From Front Porch to Back Seat: Courtship in Twentieth Century America (Baltimore: Johns Hopkins University Press, 1988), 35.

${ }^{109}$ Wini Breines, Young White and Miserable: Growing up Female in the Fifties (Chicago: University of Chicago Press, 2001), 59.

${ }^{110}$ Will Eisner, The Best of the Spirit (New York: DC Comics, 2005), 26.
} 
interested in promoting the New Deal to his readers. The Spirit's origin tale found him question why there weren't "stronger jails" for the criminals he has captured. ${ }^{111}$ He was not blind to the complexities of American society. The Spirit was aware that reform could never fully eradicate "race relations, civil rights, and the existence of poverty."112 Unlike the eternally optimistic Superman, Spirit tales were realistic in their depictions of American society. The American dream was not inevitable. One would have to battle the institutions of racism, poverty, and corporate greed in order to make a decent living.

The Spirit remained a cult favorite among the middle classes of youth culture. This was due to the originality and non-linear storytelling and art of Eisner's stories. Unlike Superman, the Spirit had no consistent logo and was able to tell a noir ' $\mathrm{B}$ ' movie every week in just seven pages. ${ }^{113}$ One story, "Meet P'Gell," wryly remarked in its opening splash page that "this is NOT a story for little boys!!"114 The Spirit offered to his readers a macabre spirit and a maverick reputation for mystery and adventure. As a middle-class hero, the Spirit represents "a distinctly American idiom and ... one of few things" which cut across class barriers. ${ }^{115}$ He seeks to make an honest living based on the wages he earns fighting crime. There is an element of non-conformity evident in the Spirit that thrilled a youth culture told to mobilize for a total war effort that would preoccupy America for the rest of the 1940s.

World War II was a watershed moment for the comic book industry. The 1940s added the dimension of war to FDR's New Deal principles for superhero tales. Democratic principles were espoused by the new war heroes, especially Captain America. Out of war came lasting staying power for superheroes. Never before had superheroes played so direct a part in the national culture. Martin Goodman, head of Timely Comics, had instructed young artists Joe Simon and Jack Kirby to develop a superhero who could reflect American patriotic principles. Simon proved receptive to the idea and created the Nazi-hunting Captain America. Captain America was not the first superhero for Timely Comics, but he would become the most popular and the face of the Golden Age, transcending even Superman. Superheroes would use WWII as a way of achieving a degree of permanence with youth culture. ${ }^{116}$

The 1940s offered the opportunity for superhero comic books to exploit home front culture and patriotism. Superheroes such as Captain America and Superman rode the antifascist feelings which permeated American society prior to the entry in the war. Reflecting the popular attitudes of American youth would allow superheroes to be supported as a representation of American democracy. Characters were created with the express purpose of capitalizing on the national interest in (and stake in) the war raging in Europe and the Pacific. The year 1941 saw Timely Comics introduce the character of Captain America and his sidekick

\footnotetext{
${ }^{111}$ Ibid., 11.

112 Warren I. Susman, Culture as History: The Transformation of American Society in the Twentieth Century (Washington D.C.: Smithsonian Institution Press, 2003), 87.

${ }^{113}$ Bob Andelman, Will Eisner: A Spirited Life (Milwaukie: M Press, 2005), 57.

${ }^{114}$ Will Eisner, The Best of the Spirit (New York: DC Comics, 2005), 43.

${ }^{115}$ Arthur Berger, “Comics and Culture,” Journal of Popular Culture 5, no. 1 (1971): 176.

${ }^{116}$ Wright, Comic Book Nation, 55.
} 
Bucky Barnes to a young audience gripped in war fever. Captain America would prove to have a lasting impact on the superhero industry through the innovation his creators used as well as the impact he had on youth public opinion about the war. $^{117}$

There were several other reasons that comic book publishing houses seized on the idea to promote the war effort. First, the war had created a large demand for alternative leisure entertainment. Comic book industry data revealed that "overall circulation tripled from 1940 to 1945. " 118 In order to keep pace with audience interest, comic book publishing houses decided to insert new characters into the wartime popular narrative. The patriotic impulses behind Captain America depict American youth culture as a morally infallible entity. In fact, Captain America stressed to his young readers that "anything is possible in America, given enough desire, ambition, and just plain hard work." "119 The masked avenger of Nazis and German spies proved that a propaganda war was being waged by comic book companies for the money of its audience. Despite wartime rationing of paper, superheroes such as Captain America came to be lasting symbols of patriotic American values.

The comic book business was booming. American GIs, young boys, and even girls thrilled to the monthly exploits of superheroes. The expansion of the comic book market brought a concurrent narrowing of the themes present in superhero titles. Simpler themes of patriotic spirit were emphasized over New Deal anxieties and concerns. Captain America, thrived on the patriotic fervor following the rise of Hitler in Germany and the fascist state of Mussolini Italy. For example, Captain America predated U.S. entry into WWII. One of Simon's first editorial decisions was to place Captain America in a timeline where the U.S. had already engaged Germany and Japan. The decision would enable Simon to directly comment upon the isolationist attitudes that prevailed before the events of Pearl Harbor. This simple but effective approach made superheroes into willing supporters of the mobilization for war. ${ }^{120}$

In this environment, Captain America debuted in Captain America Comics \#1 in March 1941, written by Joe Simon and drawn by Jack Kirby. An enthusiastic recruit named Steve Rogers is denied entry into the U.S. Army because of his frail physique. Not to be deterred, Rogers willingly volunteers for an experiment that turns him into a "super-soldier."121 Unfortunately, the lead scientist is assassinated by German saboteurs before the experiment can be replicated. Rogers avenges himself on the Germans and devotes himself to fighting war criminals as the costumed Captain America. American superiority is

\footnotetext{
${ }^{117}$ Mike Benton, The Comic Book in America: An Illustrated History (Dallas: Taylor Publishing Co., 1993), 34.

${ }^{118}$ Les Daniels, DC Comics: Sixty Years of the World's Favorite Comic Book Heroes (Boston: Bulfinch Press, 1995), 64.

${ }^{119}$ Andrew and Virginia MacDonald, "Sold American: The Metamorphosis of Captain America," Journal of Popular Culture 10, no. 1 (1976): 249.

${ }^{120}$ Mike Benton, The Comic Book in America: An Illustrated History (Dallas: Taylor Publishing Co., 1993), 33.

${ }^{121}$ Joe Simon and Jack Kirby, Marvel Masterworks: Golden Age Captain America Vol. 1 (New York, Marvel Entertainment Group, 2005), 6-7.
} 
implicit in Captain America's creation. American ingenuity can only be stunted by sabotage. Captain America represents "the strength and will" of the American people he protects from harm. ${ }^{122}$ In the face of American attitudes of uncertainty towards the war waging in Europe, Captain America represented confidence and a patriotic spirit geared towards intervention.

In contrast, Will Eisner drew on his Jewish roots when he introduced the concept of an underground hideaway that is seen in his 1940s Spirit tales. The underground hideaway concept expounded by Eisner was a way for Jews to promote entry into the war while protecting their religious and racial backgrounds. After solving crimes, the Spirit would retreat to an underground bunker beneath a cemetery. Eisner conceived of the underground shelter as a "Christlike" resurrection for the Spirit. ${ }^{123}$ Furthermore, the idea of an underground hideaway resonates with the Jewish underground resistance prior to and during WWII. The Spirit hid his true existence as a "dead" resurrection figure by going underground. Race and social class were inextricably linked in Spirit tales. Jules Feiffer, an artist on The Spirit, remarked that the Spirit was middle class with a hidden subtext of a Jewish identity. ${ }^{124}$ Like many of his peers, Eisner subtly acknowledged his Jewish heritage by hiding the Spirit's real identity.

Like the Spirit's alter-ego, the secret identity of Captain America was crucial in the juxtaposition with his masked identity. Captain America's secret identity furthered the tradition set by Superman, only for a war-time audience. Rogers's duties as Captain America often conflicted with the mundane maintenance tasks he faced as Private Steve Rogers. Captain America's secret identity as Steve Rogers reinforced his social status in the male hierarchy of 1940s America. Steve Rogers is physically too weak to fight in the frontlines for the U.S. Army, so he is relegated to K.P. duty. But when Captain America dons his costume, he is fulfilling his duty as a soldier. He does not feel confined by his secret identity. Rogers' first duty is protecting the principles of American democracy. His personal relationships were put on hold. Similarly, the course of the American economy was sacrificed in order to mobilize for total war. New Dealers believed that once the war ended, the American economy would continue to rely upon individualism and faith in the free market. ${ }^{125}$ Captain America's female relationships were strictly platonic as a symbol of his sacrifice for wartime.

One of the classic images of maleness is invoked by Rogers when he smokes his pipe in contemplation of an adventure. ${ }^{126}$ The supposedly meek Steve Rogers is drawn by Kirby with a square jaw and strong cheekbones. Captain America's frequent nemesis, the Red Skull, is a hideous Nazi war criminal.

\footnotetext{
${ }^{122}$ Ibid., 7.

${ }^{123}$ Bob Andelman, Will Eisner: A Spirited Life (Milwaukie: M Press, 2005), 55.

${ }^{124}$ Simcha Weinstein, Up, Up, and Oy Vey!: How Jewish History, Culture, and Values Shaped the Comic Book Superhero (Baltimore: Leviathan Press, 2006), 42.

${ }^{125}$ Alan Brinkley, The End of Reform: New Deal Liberalism in Recession and War (New York: Vintage Books, 1995), 199.

${ }^{126}$ Joe Simon and Jack Kirby, Marvel Masterworks: Golden Age Captain America Vol. 1 (New York, Marvel Entertainment Group, 2005), 25.
} 
Simon made an obvious distinction when he paired the Red Skull with Captain America. The Red Skull was deformed and cowardly. The blonde-haired, AllAmerican image of Captain America must contend with the Red Skull's devious and underhanded methods of violence. As a cultural marker, Captain America became an updated symbol of patriotism along the lines of Uncle Sam. ${ }^{127}$ Simon and Kirby had created a character that fulfilled the fantasies of youth culture by using traditional American archetypes. Young readers could not enlist in the army, but they could vicariously experience the patriotism the war engendered among American society by reading Captain America tales.

\section{Juvenile Delinquency and the Decline of Superheroes}

While comic book readership exploded in previous decades, the 1950s ushered in an era of significant readership reductions. The genre, and superheroes themselves, came under attack from conservative social critics. World War II had offered a distinct opportunity for comic book publishing houses to insert the superhero into a pro-war ideology. As we have seen, the visibility of superheroes within American popular culture was unprecedented. Comic book sales had reached a high point of 540 million copies sold during the year of $1946 .{ }^{128}$ However, the growing influence of superhero comic books upon impressionable youth also invited negative attention. The war hero was no longer as popular. Social critics, especially child psychologist Fredric Wertham, saw superheroes as a sinister ideology that promoted anti-democratic values and shunted the moral and physical development of children. Wertham's views on superhero comic books would be organized in his landmark book, Seduction of the Innocent. Superheroes were under attack for contributing heavily to renewed fears of a juvenile delinquency epidemic. Librarians pointed out that the aggregate sales of books paled in comparison to that of comic books. ${ }^{129}$ Wertham and his supporters contended that youth violence was presented favorably in superhero comic books. Superhero comic books were an active agent in what the National Education Journal deemed "what goes into the mind comes out in life." 130 The fallout from these criticisms changed the archetypes and commercial dynamics behind superheroes.

Comic book readership slowly declined after the conclusion of WWII. Wartime heroes such as Captain America were no longer profitable characters. ${ }^{131}$ Communism was a more ambiguous threat: superheroes could not galvanize behind the threat of a Russian attack like they could against the threat of Nazism

${ }^{127}$ Diana Schutz and Denis Kitchen, Will Eisner's Shop Talk (Milwaukie: Dark Horse Comics, Inc., 2001), 210.

${ }^{128}$ Bart Beaty, Fredric Wertham and the Critique of Mass Culture (Jackson: University Press of Mississippi, 2005), 116. The total of 540 million copies for the year of 1946 averaged out to 45 million per month.

${ }^{129} 429$ million books were sold in 1947, in stark contrast to the sales generated by comic books in 1946.

${ }^{130}$ Bart Beaty, Fredric Wertham and the Critique of Mass Culture (Jackson: University Press of Mississippi, 2005), 116.

${ }^{131}$ Captain America comic books were cancelled in 1954 until his revival starting in 1964. 
and Fascism. The Russian threat was based upon their ability to launch an atomic attack upon America. This threat proved to be vastly unpredictable in comparison to the reality of WWII's battlefields in Europe. The ambiguity of an attack upon America hampered comic book companies as they tried to retain the gains in readership during the war. Comic book companies would face loyalty tests that hampered other popular cultural mainstays such as the film industry. ${ }^{132}$ The effort to prove loyalty on the part of comic book publishers was hampered by charges of impure content shamelessly promoted to impressionable children.

Wertham stepped into the spotlight by arguing that the comic book industry generated juvenile delinquency among its readers. Superheroes were not spared in Dr. Wertham's critiques. The "holy trinity" of superheroes - Superman, Batman, and Wonder Woman - received varying levels of criticism for promoting juvenile delinquency. Wertham was allowed to make these claims because he used fantastic language in order to incite parents to worry over their children. In his article "The Comics...Very Funny!," Wertham makes the pseudo-scientific claim that "It is pretty well established that 75 percent of parents are against comic books."133 Wertham was on a crusade against the comic book industry and would make any claim that would damage the already tenuous position the industry had with parents. He emphasizes that comic books are unavoidable and largely obtainable by impressionable youth. Wertham believed that morally objectionable comic books were slipped to naïve children. He believed this was a great example of the uncaring nature of the publishing house. ${ }^{134}$

The superheroes Batman and Wonder Woman were singled out by Wertham as subverting the very tenets that built post-WWII American society. Some of the more important values considered by Wertham included an emphasis on the nuclear family, proper gender roles, and a hierarchy of responsibility. According to Wertham, Batman did not keep with the traditional expectations of a nuclear family and was fraught with homoerotic underpinnings. ${ }^{135}$ Wonder Woman did not fit any conceived notion of female domesticity and thus was neglecting her responsibility to American society. Wertham saw Wonder Woman's values as shirking the core fabric of femininity. A young patient of Wertham's replied "I buy comic books every week... One of the girls is the best fighter."136 The notion that a girl could be physically strong and assert her femininity was unheard at the start of the 1950s. Wertham and his followers saw an undercurrent of lesbianism in Wonder Woman's monthly adventures.

The relationship between Batman and Robin was supposed to be analogous to a father and son dichotomy. Batman's creators never intended to support the contention that Robin was more than Batman's trusted ward. Robin's role was to be young and devilish counterpart to the dark and sober Batman. Writers wanted to favorably contrast the similar tragic circumstances that led first

${ }^{132}$ Stephen J. Whitfield, The Culture of the Cold War (Baltimore: Johns Hopkins University Press, 1991), 141.

${ }^{133}$ Fredric Wertham, “The Comics Very Funny!,” The Reader's Digest, August 1948, 18.

${ }^{134}$ Fredric Wertham, The Circle of Guilt (New York: Rinehart and Co., Inc., 1956), 89.

${ }^{135}$ Manliness was an important consideration for many scholarly critics of the era. A man could not perform his duties as a responsible American citizen if he gave in to effeminacy.

${ }^{136}$ Wertham, “The Comics Very Funny!” 15. 
to Batman and then later to Robin, fighting crime. ${ }^{137}$ However, Wertham saw the father-son dynamic subverted by his gay reading of the Batman comic books:

At home they lead an idyllic life. They are Bruce Wayne and 'Dick' Grayson. Bruce Wayne is described as a 'socialite' and the official relationship is that Dick is Bruce's ward. They live in sumptuous quarters, with beautiful flowers in large vases, and have a butler, Alfred. Bruce is sometimes shown in a dressing gown. As they sit by the fireplace the young boy sometimes worries about his partner...it is like a wish dream of two homosexuals living together. ${ }^{138}$

Homosexuality in Batman comic books of the 1950s has been a widely discussed topic for academia and comic book fans as "self-evidently ludicrous, despite the fact that" Wertham's argument was "both relevant and convincing” at the time. ${ }^{139}$ Wertham's anecdotal evidence combines patient testimony with confident assertions. As ludicrous as they seem, Wertham's claims were not without some foundation. Despite the claims by DC of a platonic father/son relationship, many gay readers empathized with Batman and Robin.

Other dynamics of Batman comic books were criticized by Wertham. In particular, Wertham and his followers saw Batman's rogue gallery, especially the Joker, as manifestations of childhood delinquency. The Joker first appeared in Batman \#1 (1940). Although this seminal villain emerged during the World War II era, the Joker's themes and social realities resonated well after the war. Thus, it is pertinent to look at the Joker's earliest stories in order to understand why Wertham and his followers saw him as a threat to American children during the Cold War. The Joker's original depiction as a cold-blooded murderer was frightening enough to Wertham and concerned parents. However, the most problematic aspect of the Joker was that he subverted the symbolism inherent in the clown motif. A clown was an innocent jester and a staple of American childhood ever since the advent of Barnum and Bailey's Circus. The Joker's first description states outright that he is "a criminal weaving a web of death about him...leaving stricken victims behind wearing a ghastly clown's grin...the sign of death from the Joker!" "140 Such a description belies the happy associations with a clown in favor of something far more sinister and threatening to a child's previous experience and overall mindset.

In Batman \#1, the Joker ruthlessly kills traditional male authority figures. He takes a child-like joy in performing murderous acts. In one particularly gruesome scene the Joker gloats over one of his victims, exclaiming “Are you so

${ }^{137}$ Bill Finger et al., Batman Archives Vol. 1 (New York: DC Comics, 1990), 133.

${ }^{138}$ Fredric Wertham, Seduction of the Innocent (New York: Rinehart Press, 1955), 190.

${ }^{139}$ Bart Beaty, Fredric Wertham and the Critique of Mass Culture (Jackson: University Press of Mississippi, 2005), 201.

${ }^{140}$ Bill Finger et al., The Dark Knight Archives Vol. 1 (New York: DC Comics, 1992), 12. 
happy that you smile for joy, eh? I'm glad I have brought you so much cheer!”141 Critics decried the association of death with joyfulness, and saw it as inherently harmful to a child's maturation process. The Joker's use of childhood symbols epitomizes the notion that he is caught in a delinquent state. He never developed the capacity to mature as a moral adult. The Joker's deformed figure and sinister visage only contributed to the negative charges brought forth by social critics. Simply put, the Joker had no rightful place as a children's character, even as a villain. The Joker's popularity as the main antagonist of Batman meant that he could never be properly punished for his crimes against humanity and decency. The Joker's constant reappearances in Batman comic books could be explained as the permanence of a rising childhood delinquency epidemic.

The criticism of Wonder Woman contradicted many of the stated intentions of her creator, William Moulton Marston. During the 1950s, Marston challenged "the intellectuals of his era in accepting the fantastic plots and the image-driven narratives of comic books, at least in part because he thought he saw a chance to do some good."142 Marston believed that a strong female role model would empower girls to become more assertive in the domestic realm and by extension challenge the patriarchal domination of American society. Wertham disagreed with Marston's contention that Wonder Woman could be a strong exemplar of American moral values and a benchmark for rising second-wave feminism. In Wertham's professional view, Wonder Woman promoted deviance and a lesbian lifestyle to young girls under the guise of American values. Thus, Wertham would come to target specific aspects of the Wonder Woman mythos as radical feminist propaganda.

The female body was, in a way, a Cold War icon. In order to become domestic paragons of American capitalism, young girls needed to retain a proper body image. Oftentimes, American women were compared to their Soviet counterparts in Communist Russia. While Wonder Woman's body image fit the mold of a proper American woman, her supporting cast of female characters did not. Etta Candy, an aide to Wonder Woman, was portrayed in a spectacularly unflattering light according to social critics such as Wertham. Etta encouraged young girls to waste their figures on candy and other junk food. Etta defended her buxom figure by remarking that "after they took out my appendix, I could eat anything - so I did!”143 Etta's rationale failed to sway social critics who instead saw a lazy, overweight female succumbing to carnal pleasures.

Etta's role in the Wonder Woman comic book was even more damaging for Wertham when we consider that her role model was not a male. Women may have had rights in the American system, but they were never expected to display their strength. American women in the Cold War were expected to portray a frail and delicate appearance. Wonder Woman's bulging biceps and refusal to back down from her male villains shows her acting against the grain. It simply was not dignified for a woman to emulate Wonder Woman. The end of the war was

${ }^{141}$ Ibid., 15.

${ }^{142}$ Les Daniels, Wonder Woman: The Golden Age (New York: DC Comics, 2001), 12.

${ }^{143}$ William Moulton Marston, Wonder Woman Archives Vol. 1 (New York: DC Comics, 1998), 40. 
meant to "return to a less violent display of woman power in the comics" and within American popular culture. ${ }^{144}$

Wonder Woman's love interest during Marston's run on the comic book was Steve Trevor, a valued member of U.S. counter-intelligence. Trevor's ability to get into trouble in every issue made him a male version of the "damsel in distress." Feminist scholars have come to endorse these early Wonder Woman plots as a prototype of "military power expressed through a woman's body, once that body relinquishes conventional expectation."145 Of course to 1950s social critics such as Wertham this depiction of Wonder Woman was "lesbian and hence a frightening image for boys, a morbid ideal for girls.”146

Wertham's blistering attacks on superheroes such as Wonder Woman and Batman would lead to the direct involvement of the U.S. government. The Senate Subcommittee on Juvenile Delinquency was convened in 1954. The committee's charge was to investigate the link between juvenile delinquency and comic books. Once juvenile delinquency was defined, the committee would provide regulatory recommendations. Interviews with comic book writers, artists, and editors were held. However, testimony given by Wertham and social critics of comic books were given first priority by the committee's head, Senator Estes Kefauver (D$\mathrm{TN}$ ). The Subcommittee on Juvenile Delinquency was no different than similar inquiries into the film and radio industry. The main difference that distinguished the comic book industry from its earlier cultural peers was in the directness and shocking turns the interviews took. Neither side was willing to make concessions. Wertham championed himself as a moral crusader while the comic book industry presented themselves as victims of an organized witch-hunt. With the two sides dug in, the committee would have to make a difficult decision about the future of comic book content.

Wertham's testimony was starkly critical of the comic book industry's disregard for the problem of juvenile delinquency. His opening statement went into great detail about his education and prominent role in American psychiatry. Wertham's stress on credentials and his unverified claim that "to the best of my knowledge our study is the first and only individual large scale study on the subject of comic books in general” portrayed him as a larger than life figure. ${ }^{147}$ Wertham's authority was derived from his uncanny ability to make grand statements and assertions. In fact, Wertham's famous study on comic books, Seduction of the Innocent, was largely condemned by peer review because of its reliance on unscientific data and conclusions. ${ }^{148}$ Nonetheless, Wertham was able to project an authoritative voice on the proceedings which took place.

Wertham's authority was based on rather circumstantial evidence. At one point in his line of questioning, Wertham professed that "I had no idea how one

\footnotetext{
${ }^{144}$ Maurice Horn, Women in Comics (Philadelphia: Chelsea House Publishers, 2001), 115.

${ }^{145}$ Lillian S. Robinson, Wonder Women: Feminisms and Superheroes (New York: Routledge, 2004), 14.

${ }^{146}$ Ibid.

147 United States, Senate Committee on the Judiciary Hearings before the Subcommittee to Investigate Juvenile Delinquency, U.S. Congress (Washington, D.C.: Government Printing Office, 1954), 81.

${ }^{148}$ Beaty, Fredric Wertham and the Critique of Mass Culture, 196.
} 
would go about stealing from a locker in Grand Central, but I have comic books which describe that in minute detail and I could go out now and do it." "149 Wertham's strategy was to present shocking claims bolstered by dubious logic. He hoped that the impact of his claims would go straight to the moral attitudes of the committee and concerned parents. Wertham's main contention was that violence and deviant behavior was glamorized by superhero comic books. There was little moral recourse retained in superhero narratives. The main motivation for comic book publishers was to make a profit. Wertham contended that making comic book publishing houses the arbiters of morality and childhood education would be a dangerous trend for the future generations of American society.

One tactic that was used by Wertham to great effect "was to take panels and dialogue out of context in order to illustrate a point."150 We have already seen this aspect at play in Wertham's interpretation of Batman and Robin as gay partners and Wonder Woman as strong-headed lesbian subversive. However, in testimony given at the hearing, Wertham went a step further. He directly criticized the first superhero icon, Superman, by applying Nazi ideology to the origin of his name. Wertham's implication that Superman was an Ubermensch figure proved to be one of the more shocking revelations made by the anti-comic book contingent. ${ }^{151}$ Wertham's agenda assumed central prominence. Advocates for the comic book industry were hard pressed to come up with a logical defense of the profession.

Writers, editors, and artists represented and defended the industry. ${ }^{152}$ However, the man that enthralled the Senate committee was Entertaining Comics (EC) publisher and editor William M. Gaines. Gaines's EC company was notorious for putting out violent and sadistic horror comic books. Superheroes were lumped in with Gaines's coterie of hideous zombies and ghouls. The comic book industry would galvanize around Gaines's brave testimony. Gaines, in a spectacularly defiant performance, refuted many of Wertham's most pointed critiques of the comic book industry. He pointed out to the Senators present at the hearing that comic books "had attacked anti-Semitism, racism, drug addiction, and even juvenile delinquency... and stopped just short of" calling Wertham a liar. ${ }^{153}$ Unfortunately, Gaines was not able to keep up his verbal barrage against the paranoid culture that Wertham promoted. The defining moment of the hearings came in this exchange of dialogue:

\footnotetext{
${ }^{149}$ United States, Interim Report of the Senate Committee on the Judiciary Hearings before the Subcommittee to Investigate Juvenile Delinquency, U.S. Congress (Washington, D.C.: Government Printing Office, 1955), 14.

${ }^{150}$ Amy Kiste Nyberg, Seal of Approval: The History of the Comics Code (Jackson: University Press of Mississippi, 1998), 64.

${ }^{151}$ United States, Senate Committee on the Judiciary Hearings before the Subcommittee to Investigate Juvenile Delinquency, U.S. Congress (Washington, D.C.: Government Printing Office, 1954), 86.

${ }^{152}$ Including Milton Caniff, Walt Kelly, Steve Canyon, and Joseph Musial.

153 United States, Senate Committee on the Judiciary Hearings before the Subcommittee to Investigate Juvenile Delinquency, U.S. Congress (Washington, D.C.: Government Printing Office, 1954), 99.
} 
Senator Kefauver. Here is your May 22 issue. This seems to be a man with a bloody ax holding a woman's head up which has been severed from her body. Do you think that is in good taste?

Mr. Gaines. Yes, sir; I do, for the cover of a horror comic. A cover in bad taste, for example, might be defined as holding the head a little higher so that the neck could be seen dripping blood from it and moving the body over a little further so that the neck of the body could be seen to be bloody.

Senator Kefauver. You have blood coming out of her mouth.

Mr. Gaines. A little.

Senator Kefauver. Here is blood on the ax. I think most adults are shocked by that.

The Chairman. Here is another one I want to show him.

Senator Kefauver. This is the July one. It seems to be a man with a woman in a boat and he is choking her to death here with a crowbar. Is that in good taste?

Mr. Gaines. I think so.

Mr. Hannoch. How could it be worse? ${ }^{154}$

It is quite clear that the senators on the committee chose specific evidentiary materials for Gaines to respond to. A conscious decision was made to show the worst of the worst images and force Gaines into a verbal hole. While the beleaguered publisher performed admirably, the above passage sunk any momentum Gaines had garnered among the committee. Something drastic was needed to regulate the content of the comic book industry. Superheroes were no different than Gaines's horror line. Every genre of comic book was under attack. The comic book industry would quickly come up with a solution that would end calls for direct federal regulation but at the expense of freedom of content.

The committee issued its recommendations in 1955. They did not fully endorse Wertham's views. Yet, the cultural and political environment prompted the committee to come to the conclusion that "this country cannot afford the calculated risk involved in feeding its children, through comic books, a

${ }^{154}$ Ibid., 103. 
concentrated diet of crime, horror, and violence.”155 On October 26, 1954, the comic book industry took matters into their own hands. They combined resources to form the Comics Magazine Association of America (CMAA). This organization would provide the ultimate oversight on objectionable content within comic books, including superheroes. The CMAA allowed the comic book industry to continue to operate free of federal government intervention. However, this meant a severe self-censorship on publishing companies who accepted the code's tenets. The financial demise of Gaines's EC company proved the absolute power of the CMAA.

The two major publishers of superheroes, DC and Marvel, had to contend with the decisions that "forbade the presentation of crime in any manner that created sympathy for criminals" and to present respected institutional figures in a positive and respectful manner. ${ }^{156}$ This meant that vigilantes such as Batman would have to work with the police and insane villains such as the Joker would have to be sanitized to fit the CMAA's definition of criminal activity. Furthermore, the CMAA stated that women were to be depicted as pure and "never treated in such a way to stimulate the lower and baser emotions."157 This edict was aimed at strong superheroines such as Wonder Woman. The CMAA believed that comic book figures such as Wonder Woman should "emphasize the value of the home and the sanctity of marriage."158 The CMAA code which now governed superhero comic books was extremely restrictive "even by the conservative standards of the time." 159 Superheroes had been dealt a decisive blow. They would never reach the prolific sales figures or tap into the American mainstream culture as they had by the end of World War II.

\section{Superhero Revival, the Marvel Age, and the Cold War}

A new "Silver Age" for superheroes began in the 1960s. A marginalized comics market introduced new superhero archetypes for their young readers. By the early 1960s, the demonizing process that had centered on comic books had faded. New youth subcultures such as rock n' roll became the new public enemy of concerned parents. In fact, television programs became edgier as they embraced some of the rebellious aspects that rock n' roll had popularized. The superhero had survived to become the dominant genre in the comic book business. Other genres such as Western, romance, science fiction, and horror had suffered the consequences of the 1950s crackdown on objectionable content in comic books. Superheroes had survived by strictly adhering to self-censorship. The liberalization of American culture allowed superhero comic books to

\footnotetext{
${ }^{155}$ United States, Interim Report of the Senate Committee on the Judiciary Hearings before the Subcommittee to Investigate Juvenile Delinquency, U.S. Congress (Washington, D.C.: Government Printing Office, 1955), 32.

${ }^{156}$ Wright, Comic Book Nation, 172.

${ }^{157}$ Michael R. Lavin, Original Text of the Comics Code Authority (as Adopted in 1954), 23 April 2007, <http://ublib.buffalo.edu/libraries/units/lml/comics/pages/cca-lang.html> (21 December 2000).

${ }^{158}$ Ibid.

${ }^{159}$ Wright, Comic Book Nation, 173
} 
challenge the assumptions behind 1950s censorship. Comic book readers banded around the new superheroes created by Stan Lee and Jack Kirby for Marvel Comics. A burgeoning community was built through the letters columns of superhero titles. Marvel was able to position themselves as a publishing maverick. Several of their new superheroes, including the Fantastic Four and the Amazing Spider-Man were able to reflect real-world sensibilities and problems. Other heroes such as the Invincible Iron Man and the Silver Surfer examined the political landscape of the 1960s. The close bonds shared with youth culture meant that superheroes had reasserted themselves into the American national consciousness.

The 1960s saw a revival of superheroes under the industry leadership of Marvel Comics. Marvel superhero titles had always placed second in popularity and sales to DC Comics. However, the increased visibility of DC's heroes, led by Superman and Batman, actually hurt its position as number one in the comic book medium. The 1950s comic book backlash had targeted the more popular superheroes. DC Comics made the editorial decision to make their "heroes more plausible" and morally safe for young children. ${ }^{160}$ As the leader in their industry, DC Comics was counted on to provide leadership and a moral compass.

A major publisher of superheroes, DC Comics, had seen sales decline precipitously by the 1960s. Since 1944, comic book readership had declined by fifty-two percent among twelve- to seventeen-year-old American males. ${ }^{161}$ Other teenage diversions were becoming more popular than superheroes. The invention of the television set had put 56.9 million units in American households by the year 1960. ${ }^{162}$ Young readers had aptly realized that DC's superheroes had become "pale imitations of their former grandeur: myth without magic."163 Superman, Batman, and Wonder Woman were not resonating with young readers. Instead, DC's superheroes were largely seen in an adult light. The disdain for more mature superheroes is realized by the fact that by the 1960s "teenagers had a voice and vote in family affairs." 164 In addition, the liberal New Deal origins for Superman and Wonder Woman were out of favor. Jerry Siegel and Joe Shuster no longer wrote and drew Superman, thus alienating "diehard Man of Steel fans." "165 The political landscape of American youth culture had changed. The Cold War had put "liberalism on the defensive."166 The principles of DC's superheroes were being replaced by gimmickry and campy plot devices. The comic book industry needed to refine its methods for attracting new readers. This

${ }^{160}$ Greg S. McCue and Clive Bloom, Dark Knights: The New Comics in Context (Boulder: Pluto Press, 1993), 35.

${ }^{161}$ Patrick Parsons, "Batman and His Audience: The Dialectic of Culture," in The Many Lives of Batman: Critical Approaches, ed. Roberta E. Pearson and William Uricchio (New York: Routledge, 1991), 74.

${ }^{162}$ Ibid., 72.

${ }^{163}$ Greg S. McCue and Clive Bloom, Dark Knights: The New Comics in Context (Boulder: Pluto Press, 1993), 35.

${ }^{164}$ Grace Palladino, Teenagers: An American History (New York: Basic Books, 1996), 99.

165 Ron Goulart, Ron Goulart's Great History of Comic Books (Chicago: Contemporary Book, Inc., 1986), 275.

${ }^{166}$ Stephen J. Whitfield, The Culture of the Cold War (Baltimore: Johns Hopkins University Press, 1991), 31. 
is not to suggest DC was on the verge of collapsing. The revival of "Golden Age" characters such as the Flash and the Green Lantern helped to usher in a new emphasis on superheroes. ${ }^{167}$ However, in terms of cultural importance, the new "Silver Age" belonged to the upstart Marvel Comics and their new brand of superheroes.

In contrast, Marvel Comics simply wanted to survive financially under the new restrictions of the Comics Code. Their previous line of monster/horror titles had been largely sanitized after protestations by Wertham. Young writer Stan Lee and rising comic book artist Jack Kirby did not much care for the new conventions set by the Comics Code. While they did not have free rein in editorial content, Lee and Kirby cultivated a maverick image for Marvel Comics. Kirby vocally criticized the attempts of Wertham to suppress the natural urge of children "to be entertained...to be scared...to be elated." 168 Furthermore, Lee spoke to kids in an easygoing manner through Marvel's letter columns. His correspondences with teenagers were devoid of a condescending adult tone. Youth culture accepted Lee and the Marvel brand as one of their own.

Other writers focused specifically on their identification with Marvel's superheroes. Even in their infancy, Marvel characters such as Spider-Man provoked strong emotional attachments among their devoted readers. Gordon Matthews complained:

Give Spider-Man problems permanently! He no longer represents even a tragic figure, which he always has been supposed to represent. Who was comicdom's Hamlet is now, in comparison, comicdom's Old King Cole. I'd better stop here; I'm breaking my own heart with nostalgia. ${ }^{169}$

These superhero role models were put under intense scrutiny by their adoring public. A deviation from the norm established did not feel right to a fan such as Gordon Matthews. Matthews represented a core group of readers who for better or worse felt devoted to the monthly exploits of their superhero of choice. Icons such as the Fantastic Four and Spider-Man needed to progress in their character evolution but not at the expense of their core values. Superhero fandom proved very fickle in this regard. Superheroes were gradually emerging as popular role models for kids who grew up alongside them.

Martin Goodman, aging publishing head of Marvel, assigned Stan Lee and Jack Kirby to produce a superhero title that would give them a steady young audience. Lee and Kirby would tap into the youth zeitgeist. They decided to flout the traditional superhero conventions practiced by their competitor, DC

\footnotetext{
${ }^{167}$ Superhero revivalism reached a high point for DC with the creation of the Justice League of America and the re-introduction of the Justice Society of America.

${ }^{168}$ Ronald Levitt Lanyi, “Idea and Motive in Jack "King” Kirby’s Comic Books: A Conversation,” Journal of Popular Culture 17, no. 2 (1983): 23.

${ }^{169}$ Stan Lee et al., The Amazing Spider-Man \#75 (New York: Marvel Comics, 1969), 23.
} 
Comics. ${ }^{170}$ Lee and Kirby's heroes bickered and fought each other. Their universe was made as real as possible. For example, Marvel's stable of superheroes was concentrated in New York City. Lee wrote his stories with the intention of giving superheroes modern problems such as paying the rent. Many of Marvel's superheroes dealt with the controversies of the era such as the Vietnam War and a radical youth counterculture. Lee and Kirby's collaboration would produce the first family of superheroes and the beginnings of the Marvel "Universe." Debuting in 1961, the Fantastic Four ushered in the "Marvel Age" of superheroes.

The Fantastic Four started a fevered pitch among readers for anything that was under the Marvel logo. Many readers recognized the new archetype that Lee and Kirby had created. Fantastic Four \#6 saw the publication of its first letter column. Gregory Christiano raved about "the new approach towards comic mags, where the characters act like everyday people." ${ }^{\prime 17}$ The letters column had become an interactive space for the creators and fans to interact and share their opinions, ideas, and love for superheroes. In order to drive up sales and a familiarity with the Marvel brand, Lee became a self-promoter. Over time, he would run various contests espousing Marvel trivia in his letter columns as well as taking an active involvement in what the fans had to say about recent issues. ${ }^{172}$

One of the existing advantages Marvel had was the fact that they had not been as closely associated with the cultural backlash against comic books during the 1950s. ${ }^{173}$ The 1960s saw Stan Lee and Marvel introduce a new superhero archetype: a hero with real-life problems. The Fantastic Four were the perfect model of a 1960s nuclear family. Each member of the team had a defined familial role to perform. Mr. Fantastic was the father figure and elder statesman. The Thing and the Human Torch were the bickering siblings. Their squabbling was often the impetus for the Fantastic Four's problems. ${ }^{174}$ Other real-life problems the Fantastic Four encountered included acquiring enough money to rent their headquarters of operation. Teenagers could identify with the mundane nature of the Fantastic Four's dilemmas. Staples of youth culture included the Human Torch pining over myriad female crushes and the Thing constantly worrying about his hideous appearance. "Low" cultural art forms such as comic books were being accepted by the middle class. ${ }^{175}$ While the cultural authority of the Fantastic Four was low, its ability to achieve a degree of cultural power can not be overlooked.

The letters column for the Marvel titles of the 1960s is an invaluable primary source detailing the motivations and desires of youth culture. A female

\footnotetext{
${ }^{170}$ Greg S. McCue and Clive Bloom, Dark Knights: The New Comics in Context (Boulder: Pluto Press, 1993), 42.

${ }^{171}$ Stan Lee and Jack Kirby, The Fantastic Four \#6 (New York: Marvel Comics, 1962), 18.

${ }^{172}$ Stan Lee and Jack Kirby, The Fantastic Four \#9 (New York: Marvel Comics, 1963), 20.

${ }^{173}$ Matthew J. Pustz, Comic Book Culture: Fanboys and True Believers (Jackson: University Press of Mississippi, 1999), 51.

${ }^{174}$ Stan Lee and Jack Kirby, Marvel Masterworks: Fantastic Four Vol. 1 (New York: Marvel Entertainment Group, 2003), 79-80.

${ }^{175}$ Michael Kammen, American Culture, American Tastes: Social Change and the Twentieth Century (New York: Basic Books, 1999), 147.
} 
writer to Fantastic Four \#7 remarked that she liked the Human Torch because "I am fourteen and happen to like teenage boys." ${ }^{176}$ The girl's sentiment for teenage boys fit into the 1960s trend of dating. Young girls were dating more frequently and at younger ages. Dating educators frequented college campuses and emerging dating advice columns in magazines such as Seventeen emphasized that men and women should date at a younger age. ${ }^{177}$ Dashing and handsome characters such as the Human Torch were helping to facilitate interest in the other sex at an earlier age.

The case of the Invisible Girl (later Woman) deserves special attention. She performed the role of housewife for the Fantastic Four. In Fantastic Four \#3, she designs homogenous blue jumpsuits for the rest of the group. ${ }^{178}$ Kirby's rendering of the Invisible Girl is fragile and delicate. In most cases, Lee did not place her in the middle of the Fantastic Four's battles. In fact, her power of invisibility suggests she is meant not to be seen. Aggressive feminism is not one of the Invisible Girl's motives. By the end of WWII, strong female superheroes such as Wonder Woman had become obsolete. ${ }^{179}$ Most women willingly returned to the home after serving in war-related factories. They started a baby boom in the new suburbia of the American landscape. The Invisible Girl is a manifestation of post-war developments. She craves the stability inherent in the family situation of the Fantastic Four.

In many ways, the Invisible Girl mirrors the ideal feminine virtues of the early 1960s woman. She is depicted as beautiful and nurturing. The Invisible Girl's promotion of family solidarity is glamorized in an urban setting. The Invisible Girl was considered a strong role model for young girls. She was a vocal proponent of beauty. The 1960s saw the emergence of the cosmetics industry into a full-fledged economic and cultural power. On the eve of the 1960s, the American cosmetics industry for young women was a staggering $\$ 1.3$ billion. ${ }^{180}$ The cultural and economic power of the cosmetics industry was magnified by the inclusion of teenage girls. Women archetypes such as the Invisible Woman provided the impetus for the rise of industries specifically devoted to the female teenage market.

The other momentous Marvel creation was the Amazing Spider-Man in 1963. Unlike the Fantastic Four, Spider-Man was a decided loner. Under the stewardship of Stan Lee and artist Steve Ditko, Spider-Man's status as a social outcast would "mess up the hero's emotions...emphasizing his loneliness." 181 Spider-Man's alter-ego, Peter Parker, was noticeable due to his huge spectacles and a square personality. Unlike Clark Kent, Parker was not pretending to be a social outcast. Parker consistently struggles to earn money as a freelance photographer for the Daily Bugle. Readers rooted for Parker to overcome his

\footnotetext{
${ }^{176}$ Stan Lee and Jack Kirby, The Fantastic Four \#7 (New York: Marvel Comics, 1962$), 18$.

177 Beth L. Bailey, From Front Porch to Back Seat: Courtship in Twentieth Century America (Baltimore: Johns Hopkins University Press, 1988), 124.

${ }^{178}$ Lee and Kirby, Marvel Masterworks, 60.

${ }^{179}$ Maurice Horn, Women in the Comics (Philadelphia: Chelsea House Publishers, 2001), 115.

${ }^{180}$ Bailey, From Front Porch to Back Seat, 71.

${ }^{181}$ Susan Wood, The Poison Maiden and the Great Bitch: Female Stereotypes in Marvel Superhero Comics (San Bernardino: R. Reginald The Borgo Press, 1974), 5.
} 
bookish looks and meager financial situation. He mirrors the typical teenage boy experience by acknowledging his identification as an everyman figure.

Spider-Man was reminiscent of the liberal "Golden Age" of superheroes. Liberal superhero ideology had ceased its popularity by the 1960s. Readers did not want a superhero beholden to a specific political ideology. Stan Lee was shrewd enough to keep Spider-Man's politics ambiguous. In fact, Spider-Man's liberal leanings were balanced out because he was "a subtle persuader, fashioning and reflecting public and popular attitudes under the rubric of entertainment."182 Spider-Man was a comfort to many young readers. He was just an ordinary boy underneath his mask. Furthermore, as a teenager himself, Spider-Man was able to connect with readers in a way that was not possible with older superheroes. He was "used skillfully to bridge the generation gap" between 1960s American youth and their older parents. ${ }^{183}$ Spider-Man's invocation of a new liberalism allowed him to serve as a mediator for the youth culture he emulated and their adult generation.

In an era of nuclear proliferation, Spider-Man offered comfort to his young readers. Spider-Man was accepted by youth culture because he offered an alternative political vision, one that was simpler than Cold War machinations. His popularity was predicated on his natural distrust of the adult establishment. In fact, liberalism increasingly became associated with youth. Youth figures and institutions such as Students for a Democratic Society and the counterculture embodied a "New Left." Spider-Man demonstrated the same principles of a growing number of disaffected youth who disdained the adult realm. Spider-Man achieved broad readership among young children to college students because he dealt "fundamentally with titanic battles between a teenage superhero and middleaged supervillains." 184 The captions contained in the Amazing Spider-Man comic book went against the grain of Cold War rhetoric. In Amazing Spider-Man \#2 a narrative caption describing the elderly villain, the Vulture, exclaims:

For days, a new and ominous danger menaced the vast city of New York! No man knows where he'll strike next! No one can cope with this new, awesome threat! Without warning, without the slightest sound, he strikes! ${ }^{185}$

The untrustworthiness of the adult world is implicitly contrasted to the unpredictability of the nuclear bomb. Spider-Man's youthful idealism is capable of stopping adult aggression.

The threat to youthful principles was one of the central tenets of SpiderMan’s 1960s plots. Spider-Man's origin is steeped in the interaction between

182 Salvatore Mondello, "Spider-Man: Superhero in the Liberal Tradition," Journal of Popular Culture 10, no. 1 (1976): 236.

${ }^{183}$ Ibid., 234.

${ }^{184}$ Ibid., 233.

${ }^{185}$ Stan Lee et al., Marvel Masterworks: The Amazing Spider-Man Vol. 1 (New York: Marvel Entertainment Group, 2004), 42. 
ideals and greed. Upon receiving his spider powers, Spider-Man decides to use them for profit. When he is taken advantage of, Spider-Man refused to stop a burglary. He bitterly states to a cop, "Sorry pal! That's your job! I'm thru being pushed around -- by anyone! From now on I just look out for number one -- that means me!"186 As a result, the same burglar goes out and kills Spider-Man's surrogate father, Uncle Ben. Lee argued that youth culture had become too focused upon the individual. Lee's maxim "with great power, comes great responsibility" resonated because of its application to teenage behavior. ${ }^{187}$ Rebelliousness held consequences for the individual. Moral teachings contained in the Amazing Spider-Man were indicative of the growing teenage advice column trend in the 1960s. American youth were given advice on how to conduct every aspect of their teenage lives through magazines such as Seventeen. ${ }^{188}$ Both superheroes and advice columns were a forum for teenagers to express their own distinct views and to develop a shared understanding towards trends and proper behavior.

The story arc "Spider-Man No More" (Amazing Spider-Man \#50, 1967) represents an attempt by Lee to show what can happen to American society when a superhero is compelled to lose faith in his ethics. At the beginning of the story, Spider-Man ruefully soliloquizes, "No matter what I do, half the population is scared stiff of me!”" ${ }^{89}$ He assumes the position of a misunderstood youth. In terms of a cultural analog, Spider-Man's musings place him alongside the growing youth hippie movement of the 1960s. Many adults feared another round of childhood delinquency. A new liberalized sexuality among teenagers "challenged and denied the mores of their society." 190 Teenage rebellion was on the defensive from the more conservative elements of American society. As a masked superhero, Spider-Man was easily stereotyped. His crime-fighting efforts are easily distorted into a negative perception because of his secret identity. In addition, a masked vigilante who uses fantastical powers to fight crime created fear in Spider-Man's world. Spider-Man's social ostracism is magnified because he does not fit the social conventions of a law enforcer.

In "Spider-Man No More," Spider-Man struggles with the fact that he can't lead the life of a typical teenager. The need for a normal teenage social life combined with public fear of Parker's Spider-Man persona leads him to give up being Spider-Man. Lee's implied argument in the story was that the American adult establishment was wrong to condemn the unfamiliar. Crime "begins to plague the startled city" immediately after Parker gives up the mantle of SpiderMan. ${ }^{191}$ Parker has a fulfilling personal life but the city he is sworn to protect is in utter chaos. It takes a prolonged absence for the general populace to realize

\footnotetext{
${ }^{186}$ Ibid., 10.

${ }^{187}$ Ibid., 13.

${ }^{188}$ Grace Palladino, Teenagers: An American History (New York: Basic Books, 1996), 102.

189 Stan Lee et al., Marvel Masterworks: Amazing Spider-Man Vol. 5 (New York: Marvel Entertainment Group, 2004), 215.

190 Beth Bailey, "From Panty Raids to Revolution: Youth and Authority, 1950-1970," in Generations of Youth: Youth Cultures and History in Twentieth-Century America, ed. Joe Austin and Michael Nevin Willard (New York: New York University Press, 1998), 188.

${ }^{191}$ Lee, Marvel Masterworks: The Amazing Spider-Man Vol. 5, 224.
} 
they need Spider-Man to protect them. "Spider-Man No More” is a parable for the breakdown of social interactions between 1960s youth culture and the fearful adult generation. Similarly, the youth generation was at the forefront for sustaining the anti-war movement and civil rights movement. Youth culture "had to find consensus in an era of conflict" analogous to Spider-Man. ${ }^{192}$ Lee and Ditko's Spider-Man set the tone for new superheroes who confronted the realities of the adult world with a sense of heightened cultural cognizance.

Spider-Man was not the only superhero to deal with real-world problems. Marvel had a whole host of diverse characters which reflected the realities of American youth culture circa the 1960s. Tony Stark, also known as the armored avenger Iron Man, was one of these figures. Iron Man's origin lay in his position as one of the most important weapons developers at the time of the Vietnam War. The escalating arms conflict of the Cold War had transformed advanced weapons development into an industry of national prestige. America was no different. By the 1960s, the Soviet-U.S. arms race had furthered the development of deadlier hydrogen bombs, ICBM missiles, and napalm. In the Marvel “universe,” Stark's weapon innovations were considered an integral part of the U.S. effort to overtake the Soviet Union in new war technologies. On the eve of U.S. entry into the Vietnam War in 1964, Stark was ordered to field test a new armor-suit technology that would help produce a new breed of American super-soldiers ${ }^{193}$. Stark was deployed to Vietnam in order to infiltrate a secret Vietcong military base using his newly created armor.

Unfortunately, Stark was caught in a trap where he suffered critical wounds to his heart. Using his “iron” armor, Stark was able to survive and decisively foil a Vietcong plot to use his armor blueprints against the U.S. Army. Tony Stark had now become the avenging vigilante known as "Iron Man." Iron Man's subsequent adventures proved crucial to the Vietnam conflict as he foiled several nefarious plots from communist sympathizers such as the megalomaniacal Mandarin and the Soviet-employed Titanium Man. In this way, Iron Man's message was an ambiguous mixture of the New Left and Cold War paranoia. As a fictional superhero comic book figure, Iron Man incorporated the tension of Cold War history for his youthful readers. The changing political climate had a drastic effect on youth culture and their superheroes. The new heroes of Marvel Comics had become "a recognizable, believable reality” for teenagers. ${ }^{194}$

At first glance, Iron Man is an ideal figure for right-wing politics. He snuffs out Communist plots and provides new weapons for the American establishment. However, as we have seen from the "Golden Age" example of Captain America, blind patriotism was not enough to sustain comic book sales. Iron Man remained popular with his readers because he possessed both the strengths and weaknesses of 1960s American society. In his civilian guise, Iron Man was a weapons manufacturer and inventor. He is a product of the Cold War

\footnotetext{
192 Salvatore Mondello, “Spider-Man: Superhero in the Liberal Tradition,” Journal of Popular Culture 10, no. 1 (1976): 236.

193 Stan Lee et al., Marvel Masterworks: The Invincible Iron Man Vol. 1 (New York: Marvel Entertainment Group, 2003), 3-4.

${ }^{194}$ Peter Sanderson, Marvel Universe (New York, Harry N. Abrams, Inc., 1996), 15.
} 
arms race. Tales of Suspense \#39 recounts the tale of Iron Man's origin. Tony Stark is able to invent his suit of armor because of his frail heart. ${ }^{195}$ The origin tale shows American inventiveness comes out of perceived weaknesses. American society of the 1960s was similarly determined to create success out of failure. The creation of the hydrogen bomb was due to the failure to keep the secret of the atomic bomb out of the Soviet Union's hands. Similarly, the first landing of the moon by Americans (1969) was in reaction to the perceived need to match and surpass Soviet successes in space exploration.

Iron Man represents a distinctly American entrepreneurial spirit. Iron Man, as Tony Stark, had become too preoccupied "with being the kinds of people others wanted them or expected them to be."196 Iron Man's supporting cast expected him to portray a confident manner as befitted a handsome socialite with wealth. His status as a rich and philanthropic playboy is depicted at odds with his violent occupation. Many of Iron Man's early plots dealt with the unforeseen problems of technological development. In Tales of Suspense \#45, ethical questions are raised towards the existence of Iron Man. Such advanced forms of weaponry could easily fall into the wrong hands. The world might be better off if Iron Man did not exist. Iron Man's armor and the hydrogen bomb may be "fantastic scientific discoveries" but the fact remained that they were potentially too dangerous for their own good. ${ }^{197}$ Atomic technology was both a boon to a society and a broader threat of looming nuclear annihilation.

Lee took Cold War tensions further through the character of the Incredible Hulk. The Hulk was the result of a gamma-ray bomb experiment gone awry. Atomic experimentation was an ambivalent development for Lee. The Hulk's alter-ego, Bruce Banner, is no longer in control of his own actions. ${ }^{198}$ Instead, a monstrous green creature creates havoc in his place. Science has given Banner great and fantastical possibilities but with a heavy price. The collective American spirit to create is subverted because the Hulk has been cast out of his society. In the larger framework of the Cold War, Iron Man and the Hulk provoked discussion amongst Marvel's young readers and would make Lee into a modern philosophical figure.

The New Left largely rejected the ideological premises behind the Cold War. General disaffection with the establishment had become a prominent feature of youth political philosophy. Superheroes such as the Silver Surfer embodied the views of the New Left by becoming philosophical paragons for worldly problems. $^{199}$ Over the course of seventeen issues (1968-1970), the Silver Surfer confronted the central problems which faced the human race. As an alien, the Silver Surfer was well suited as an outside observer. His judgments place him in the role of a "metaphysical" entity capable of distilling a distinct worldly vision

\footnotetext{
${ }^{195}$ Lee, Marvel Masterworks: The Invincible Iron Man Vol. 1, 5.

${ }^{196}$ Michael Kammen, American Culture, American Tastes: Social Change and the Twentieth Century (New York: Basic Books, 1999), 157.

${ }^{197}$ Lee, Marvel Masterworks: The Invincible Iron-Man Vol. 1, 94-5.

198 Stan Lee et al., Marvel Masterworks: The Incredible Hulk Vol. 1 (New York: Marvel Entertainment Group, 2003), 15.

${ }^{199}$ Dr. Strange, the Sorcerer Supreme, would also become a figure whose artistic depiction rested largely with the 1960s New Left.
} 
from extensive observations. ${ }^{200}$ The Surfer was a moral judge for American youth culture. He sees the world's inequities as they existed during the 1960s. Foreign policy obligations prevented the United States from devoting attention to the Silver Surfer's principles. Instead, the United States focused its attentions on saving other continents from Communism. ${ }^{201}$ His refusal to take part in the nuclear rhetoric of the Cold War showed that the Silver Surfer had a natural distrust of adult conventions. His distrust is balanced by the Surfer's faith in the inevitable triumph of humanity.

In an era of conflict and nuclear proliferation, the Silver Surfer rationalized that humanity must strive for peace and a general sense of community. ${ }^{202}$ The Silver Surfer actively wondered if humanity was capable of achieving his ideals. Lee wrote the Silver Surfer with varying levels of anxiety for the older American generation. The Silver Surfer characterized the adult world as a society "goaded by emotion...driven by savage pride."203 The Silver Surfer sides with youth because they are innocent of any social prejudices. They offered new hope to an America on the brink of nuclear annihilation.

The irony of the Silver Surfer series was that it did not attract enough young readers and the title was cancelled in 1970. However, the legacy of the Silver Surfer had important implications for the evolution of the superhero during the 1970s. The Silver Surfer demonstrated that a superhero could belong "to Western religious mass culture." 204 Up until now, superheroes had stood in for the populist ideals of the middle class and capitalism. In his lamentable state, the Silver Surfer represented a paradigmatic shift. He could preach a doctrine that was not tied to the traditional values of capitalism that had always been espoused by the comic book industry. Furthermore, the Silver Surfer reflected a growing tension between youth cultural ideals and mainstream American society. His social laments would inspire a growing movement in the comic book medium for a more mature superhero. These new titles focused on the inner workings of the superhero dichotomy and the failure of youth culture to accept the adult generation's ideals.

Superhero titles tried to extend their influence into more diverse cultural topics as their young audience aged. Green Lantern and Green Arrow provided direct social commentary on the cultural and political dilemmas facing American youth. The Uncanny X-Men highlighted the racial divisions of American society by focusing on cultural segmentation. Other superheroes such as Batman and Captain America continued to thrive by combining the archetypes that had made them successful. As the 1960s ended, superheroes began to explore ever more

\footnotetext{
200 Jean-Paul Gabilliet, "Cultural and Mythical Aspects of a Superhero: The Silver Surfer 19681970,” Journal of Popular Culture 28, no. 2 (1994): 204.

${ }^{201}$ Stephen J. Whitfield, The Culture of the Cold War (Baltimore: Johns Hopkins University Press, 1991), 57.

202 Stan Lee et al., Marvel Masterworks: The Silver Surfer Vol. 1 (New York: Marvel Entertainment Group, 2003), 46.

${ }^{203}$ Ibid., 48.

${ }^{204}$ Jean-Paul Gabilliet, "Cultural and Mythical Aspects of a Superhero: The Silver Surfer 19681970,” Journal of Popular Culture 28, no. 2 (1994): 210.
} 
complex and mature themes that belied their image as a disposable popular entertainment medium.

The 1960s provided a rebirth for Batman. Before the 1966 TV show starring Adam West, DC's editors had begun to seriously consider canceling all Batman titles. While the TV show may not have been particularly faithful to the mythos of Batman, the rabid popularity of the TV program renewed interest in the original source material. Instead of continuing to remain beholden to the camp craze that had permeated American pop culture, Batman's overseers wanted a return to his roots as a dark vigilante of the night. This version of Batman would once again stalk the streets of Gotham City as a wraith-like figure to battle bizarre and grotesque villains. The ham-fisted sci-fi plots and soap opera elements which had been put in place following the implementation of the CMAA in 1954 were largely abandoned. Once again, murderous and sinister villains such as the Joker and Two-Face reappeared in the pages of Detective Comics and Batman.

The best stories of this era in Batman's long and storied comic book history have the hero confronting social decay and urban blight. In particular, "There is No Hope in Crime Alley" examined the efforts to eradicate poverty. Lyndon B. Johnson's “Great Society” program was commented upon in a way which did not pass judgment but highlighted the injustices of 1960s and 1970s city living. The Batman listens to a raged denizen of Gotham City proclaim, "You chase international criminals...So how come you're preventing a common mugging?”205 A thoughtful internal debate about America's equal parts prosperity and inequality dominated Batman's quest against crime. This Batman was not the jolly adult figure to Robin fighting dinosaurs and aliens. Rather, the Batman of the 1970s had become a tortured, conflicting figure which resonated with an America that was painted in shades of gray.

Perhaps the most startling development was Captain America's rejection of the American government and the adoption of a new codename, Nomad (1974). The Vietnam War had made patriotism an ambiguous concept for many Americans. Captain America's decision to go against the grain reflected Marvel's keen awareness of the cultural zeitgeist. Captain America now supported an American ideal, not any particular presidential administration's policies. Most comic book fans saw this as Captain America upholding an indefinable American spirit in the face of government corruption. In fact, a reader of "The Coming of Nomad" story arc saw Captain America confront the "pain of metamorphosis; the instinctual trust in the old and familiar, challenged by the vague and confused stirrings of the future." ${ }^{206}$ The evolutionary arc of Captain America corresponded to the critiques of federal authority and privilege. Captain America even loses faith in the U.S. government when it is revealed that the President is behind a committee to subvert the American democratic process. ${ }^{207}$ Captain America shared the contention of many anti-war advocates when he declared, "One of the

\footnotetext{
205 Dennis O’Neill et al., Batman in the Seventies (New York: DC Comics, 1999), 17.

206 Andrew MacDonald and Virginia MacDonald, "Sold American: The Metamorphosis of Captain America,” Journal of Popular Culture 10, no. 1 (1976): 251.

207 The President, while not identified as Richard Nixon, is a clear facsimile. The organization CRAP that Captain America confronts is an obvious nod to the Watergate scandal.
} 
main reasons that our government has begun to exist of and for itself rather than for those it purports to serve is that we have allowed it to."208 Such sentiments continued to reflect a growing ambiguity about the nature of the Cold War. Marvel was not shy about showing the social tensions at play through their existing characters.

One set of characters that became synonymous with the civil rights struggle was Marvel's X-Men. ${ }^{209}$ Before the debut of Uncanny X-Men in the mid 1970s, the original X-title could not distinguish itself from the myriad other team books on the superhero market. Originally debuting in 1963, the fledgling title was cancelled in 1969 due to poor sales figures. However, in 1975 Marvel decided to re-launch the concept of the X-Men under the eventual title Uncanny $X$-Men. Several popular characters were introduced. Mutants such as Wolverine, Nightcrawler, Kitty Pryde, and Colossus have remained fan favorites to the present day. Most importantly, Uncanny X-Men tackled social and cultural issues head-on which the original title had somewhat eschewed for more traditional superhero tales. The X-Men were an allegory for minority civil rights, yet they also existed because of "increased radiation in the Earth's atmosphere."210 The X-Men's enduring mythos places them at the center of Cold War political machinations and the frequently cited civil rights movement.

It was no surprise that young minorities of various ethnic groups thrilled to the monthly exploits of the X-Men. Civil rights groups such as the Black Panthers and American Indian Movement (AIM) demanded radical change through militant means. However, each of these groups derived their strength from their sense of community. Similarly, Wolverine expressed the purpose of the X-Men by stating, "Most of us were loners 'fore we became X-Men. The Team's kinda given us the family we never had." 211 Of course, the X-Men could dramatically assert their right to co-exist with their human peers. The X-Men comic book would have been boring to superhero fans if there was not action and conflict. The genius behind the title was its ability to subtly include cultural references while distinctly remaining a superhero comic book. Allegory had become Marvel's best friend for injecting real world themes into their Marvel universe.

While Marvel dabbled in allegory, DC decided to have their superheroes confront real world problems. The famed Green Lantern/Green Arrow comic books (1970-1972) had the duo confront a wide range of social problems, most famously racism. Green Lantern has no answer for a black man when he questions why the superheroes have done nothing for the black race. ${ }^{212}$ Other

\footnotetext{
${ }^{208}$ Steve Englehart et al., Captain America \#180 (New York: Marvel Comics, 1974), 18.

${ }^{209}$ Two other characters, both black, would deal with civil rights issues. The Black Panther and Luke Cage (Marvel Comics) confronted racist villains while asserting their position as powerful superheroes. These characters assured readers that the color line did not matter when it came to saving the world. DC would introduce a similar character by the name of Black Lightning.

210 Richard Reynolds, Superheroes: A Modern Mythology (Jackson: University Press of Mississippi, 1994), 84.

${ }^{211}$ Chris Claremont et al., Marvel Masterworks: The Uncanny X-Men Vol. 4 (New York: Marvel Entertainment Group, 2004), 3.

${ }^{212}$ Dennis O’Neill et al., Green Lantern/Green Arrow Vol. 1 (New York: DC Comics, 2004), 15.
} 
social issues that the Green Lantern and Green Arrow encountered in their teamup were Native American civil rights, child welfare, corporate corruption, war, and the hippie subculture. The writer behind Green Lantern/Green Arrow, Dennis O'Neill, saw as his goal to devote each issue to a particular social or cultural concern. He actively wanted to challenge the assumption that had dominated the superhero genre for a long while; that they were just for kids. ${ }^{213}$ The Green Lantern/Green Arrow stories produced under O’Neill's stewardship represented an even more overt example that superheroes were conscious of the American national mood, attitudes, and cultural mores.

"Who Watches the Watchmen?”: The Anti-Heroes of the 1980s

Superheroes became much darker following the end of the Cold War. A new distribution method known as the direct market helped to facilitate a radical new archetype of the anti-hero. Both new and established characters such as the Punisher and Daredevil embodied anti-heroism. The comic-book writers of the 1980s deconstructed the "Golden Age" superhero myth to its essential elements and found them lacking in the social and political context of the 1980s. Two graphic novels, The Dark Knight Returns and Watchmen, signaled an end to the Silver Age for superheroes. The effects left by the 1980s have left their mark on today's superheroes. New readers, especially young, had become almost impossible to attract for even the biggest companies. The reliance on loyal readers made superheroes into a convoluted medium.

The direct market concept, developed by comic book entrepreneur Phil Seuling, changed the way superheroes were presented to a dwindling fan base. Estimated monthly circulation of comic books had steadily declined to 18.5 million in 1979, down from 59.8 million in 1952. ${ }^{214}$ Seuling eliminated the distribution middleman by directly dealing with comic book publishers to sell their products. As a result, the superhero narratives began to reflect the tastes of an elite subculture of comic book fans. This aging subculture began to demand certain topical themes in order to keep interest in the superhero genre. One of the overriding desires of the comic book subculture was an injection of even more realism into their superhero tales. Superhero plots took on adult themes and promulgated a disdain for the cultural and political environment of the 1980s. The populist and innocent milieu of the 1960s had been replaced in favor of a darker and more violent superhero paradigm.

Comic book entrepreneur Phil Seuling grew to love superheroes and comic books growing up in the 1950s. His superheroes were found in the numerous newsstands and candy shops of America. Many youths, including Seuling, would collect back issues of superhero comics at garage sales. However, by the 1970s, the comic book business ran into major financial and distribution problems. Candy shops had virtually disappeared from the cultural landscape as a

${ }^{213}$ Ibid., 4-5.

${ }^{214}$ Patrick Parsons, "Batman and His Audience: The Dialectic of Culture," in The Many Lives of Batman: Critical Approaches, ed. Roberta E. Pearson and William Uricchio (New York: Routledge, 1991), 68. 
place to purchase the latest adventures of Superman. Newsstand owners did not much care if their comic books sold well. Their main source of income was the daily tabloids and big-time newspapers such as the New York Times and Washington Post. Seuling remarked that the newsstand owners "didn't care" about superheroes, they had become a "novelty" in their eyes. ${ }^{215}$ The removal of retail space for new comics meant that fans grew increasingly distant from their peers and the superhero medium.

The comic book market was in decline due to the continued cultural impact of television. Americans perceived that comic book superheroes were campy material meant only for the young to enjoy on the path to adulthood. The movement away from campy plots in comic book titles was not in line with popular conceptions of the superhero. Seuling's direct market was conceived as a remedy to the problem of attracting new readers whose only exposure to superheroes was Adam West's portrayal of the "Caped Crusader." Seuling, along with Denis Kitchen, organized superhero fandom into "kindred spirits" who all "seemed to love comics." 216 Seuling and Kitchen recognized that the superhero business needed strong personal ties between the fans and creators in order to remain profitable and relevant. In particular, Seuling convinced the major comic book companies of the efficacy of the direct market. His arguments made sense financially to the companies but also appealed to fans tired of searching numerous grocery store racks for their favorite titles each month. A direct market for comic books could reduce business expenditures and also promote intimate ties to the established fandom. Seuling's decision to sell directly to comic book specialty stores effectively made the superhero readership into an elite subculture. A smaller core readership meant that companies such as Marvel and DC did not have to worry as much about attracting new readers. Instead, they could appeal to their devoted clientele by creating story arcs that required knowledge of previous events in a superhero's history.

Marvel's huge 1984-85 crossover event, Secret Wars, involved nearly all the most popular characters of the Marvel Universe. Direct appeals could be made to Marvel fans in Secret Wars. For example, we see Spider-Man acquire a black variant of his Spider-Suit, which became a fan favorite moment. ${ }^{217}$ Crossover events allowed a devoted fan base to get excited about their superheroes once again. Other developments in the crossover phenomenon were less encouraging. Secret Wars demonstrated that Marvel had begun to write for purely profit-making motives. Many fans of individual titles such as the Uncanny $X$-Men and the Incredible Hulk felt that writer Jim Shooter's unfamiliarity with the various superheroes cheapened their core values and ethics. In the Secret Wars introduction, Shooter admits that he was brought in largely as a glorified promoter for an upcoming toy line which ironically never materialized. ${ }^{218}$

${ }^{215}$ Diana Schutz and Denis Kitchen, Will Eisner's Shop Talk (Milwaukie: Dark Horse Comics, Inc., 2001), 285.

${ }^{216}$ Stanley Wiater and Stephen R. Bissette, Comic Book Rebels: Conversations with the Creators of the New Comics (New York: Donald I. Fine, Inc., 1993), 92.

${ }^{217}$ Jim Shooter, et al., Secret Wars (New York: Marvel Entertainment Group, 2005), 209.

${ }^{218}$ Ibid., 3. 
The direct market allowed comic book artists and writers more notoriety and exposure to their fans. The presence of an artist such as Neal Adams could immediately propel sales of a particular title. Seuling stated that "Marvel saw Thor experience a tremendous burst of sales simply because they changed the artist."219 A direct market emphasized that the comic book companies were reliant on fan interests to an extent never seen before. Adams has theorized that fan opinion "is the end of the argument" for decisions made on superhero titles. ${ }^{220}$ Popular artists and writers gained more control over their work as a result of fan demands.

Frank Miller, the writer and artist of The Dark Knight Returns, was able to use his success with Batman in order to gain complete ownership over the title Ronan and the later Sin City series. Miller claimed his newfound creative freedom was realized because of a growing perception that "the comics industry is dominated by two publishers, who don't believe in or even understand what comics can be.”221 The two major comic book companies, DC and Marvel, were losing their cultural identification with their stable of superheroes. Writers such as Miller and Alan Moore began to be identified as the purveyors of a fan culture preoccupied with creator idolatry. Fans began to follow the careers of the writer/artist, rather than a specific superhero character or company. The fact that Spider-Man was published by Marvel became a less important cultural identifier. The direct relationship between a fan and the creator mirrored the effects of Seuling's direct market innovations. Marvel and DC were seen as the problematic but necessary middlemen. Even if the two companies had lost touch with the contemporary superhero fan, they allowed the creator to bring his superhero tales to his audience. Seuling conceived of the direct market as a way of giving more power to the discerning comics fan. While the direct market eased the financial burdens of the publisher it also recast them in the new role of supplier. The days of the 1960s where Stan Lee could create a fan culture obsessed with the entire Marvel brand was over.

Marvel and DC had to adapt to the changes of the direct market by increasingly becoming beholden to an elite subculture of intensely devoted fans. The direct market made DC and Marvel look for a superhero archetype which would appeal to the elite sub-culture of comic book fandom. The vigilante, also known as an anti-hero, was one of the most successful innovations of the 1980s. The legacy of the anti-hero was so widespread that its formulaic conventions continue to permeate superhero narratives today. Anti-establishment figures such as the Punisher and Daredevil proved popular largely because they reflected the mores and popular attitudes of the 1980s. ${ }^{222}$ Furthermore, each of these violent vigilantes confronted many of the social fears youth culture faced during the 1980s epoch. The following is an examination of each of these figures with a

\footnotetext{
${ }^{219}$ Schutz and Kitchen, Will Eisner's Shop Talk, 296.

${ }^{220}$ Jim Shooter, et al., Secret Wars (New York: Marvel Entertainment Group, 2005), 335.

${ }^{221}$ Patrick Parsons, "Batman and His Audience: The Dialectic of Culture," in The Many Lives of Batman: Critical Approaches, ed. Roberta E. Pearson and William Uricchio (New York: Routledge, 1991), 35.

${ }^{222}$ Other notable anti-heroes that became popular in this era were Wolverine, the Swamp Thing, Venom, and Sandman.
} 
special emphasis on how they interpreted the youth paradigm and how effective they were in adopting the attitudes of a politically charged and economically privileged American culture.

The new superhero vigilante as embodied by the Punisher reflected more mature tastes and eschewed youthful idealism for gritty realism. Established superheroes such as Daredevil also began to incorporate darker and dystopian attitudes. Secondly, two landmark graphic novels of the 1980s, The Dark Knight Returns and Watchmen, revised the superhero narrative in order to reflect a new mindset of American youth culture. ${ }^{223}$ The superhero narrative would soak up the antipathy and anxieties which featured prominently in post-Cold War American culture. The Dark Knight Returns and Watchmen can be considered representative of the 1980s superhero as their themes have been widely imitated and expounded upon into modern times. The radical changes to the superhero genre of the 1980s can be explained by the dynamics of Wall Street corporatism and the end of the Cold War. The "Me! Me! Me! Generation" was a constant concern of the period. A more realistic superhero archetype was needed to explain the political and cultural shifts to a youth group that had grown accustomed to economic abundance and prosperity.

The Punisher was the first of the "anti-heroes" to achieve a platform for his views, first appearing in the Amazing Spider-Man \#129 in 1974. His appearance was as an antagonistic foil for Spider-Man. The Punisher is convinced that Spider-Man's crime-fighting activities set a dangerous precedent for society. The Punisher explains his motives to Spider-Man by declaring "you're all alike...using whatever means to get control of the public...drugs, gambling, loan shark operations." ${ }^{224}$ The Punisher clearly disdains the idealism behind superheroes like Spider-Man. He sees Spider-Man's crusade against crime as an insincere and publicity seeking stunt. The Punisher sees justice in clear black and white. He does not shy away from killing his adversaries. They are merely obstacles in the way of his vengeful crusade against crime in all its myriad forms. The Punisher revels in the political and social clichés of the 1980s. Youth culture would confront the widespread perception "that teenagers as an age group are the hapless victims of a stagnant economy and a violent society." 225 The Punisher is an incorruptible figure that uses extreme ends to instill justice in his world. His ideals are vastly different from past conceptions of the nature of heroism.

The Punisher's simple views on societal justice contrast with the liberal politics of Spider-Man. Spider-Man has consistently maintained non-lethal methods in confronting such foes as the Green Goblin and Doctor Octopus. Spider-Man hands over defeated criminals to the New York police force even though they distrust him. By the 1980s, Spider-Man's brand of liberal justice was

\footnotetext{
${ }^{223}$ These two graphic novels should be considered representational of the era. A flood of superhero comic books dubbed "graphic novels" entered the scene, including Arkham Asylum, The Killing Joke, Metalzoic, Star Raiders, and Mr. Punch. Furthermore, story arcs of long running superhero titles appeared in trade paperback form often designated somewhat erroneously as graphic novels.

${ }^{224}$ Gerry Conway et al., Amazing Spider-Man no. 129 (New York: Marvel Comics., 1974), 16.

${ }^{225}$ Grace Palladino, Teenagers: An American History (New York: Basic Books, 1996), 256.
} 
being replaced in favor of the Punisher's stark and uncompromising judicial standards. The Punisher sees no need for police involvement. In Captain America \#241 (1979), he emphatically states his views on criminal activity: "Rights? They gave up their rights when they chose the path of crime! Now it is my job to punish them...AND THE PUNISHER NEVER MISSES!"226 The Punisher's alter ego, Frank Castle, saw his family murdered by the mob in broad daylight with the police unable to do anything due to incompetence and corruption. His origin has widely been credited with his disdain for the American traditions of law and order. Criminals do not deserve due legal process. The refrain for a typical Punisher comic of the 1980s was:

He stands amid carnage, one man, rightly, wrongly-Dedicated to the waging of a lonely, unending battle. One man who has set himself above all laws, all codes, but his own. One man... ${ }^{227}$

This statement is a reflection of the disaffected youth culture of the 1980s. As the overseer of the slums and dark alleyways of New York City, the Punisher has developed a "seen it all cynicism." ${ }^{228}$ Youth culture's influences during the 1980s all had an element of apathy with the mainstream American society. Cultural critic Ryan Moore has deemed this period as a "predominance of aggressive indifference.”229 Cynicism in the mainstream culture has greatly affected the Punisher's crime-fighting habits. His violence is justified by the pervading notion that there is no moral prerogative in giving criminals legal due process. The Punisher did not care about any philosophical distinctions between right and wrong. He is a product of a "pessimistic political culture" in which he must keep order in a virtual wasteland of political and philosophical thought. ${ }^{230}$

The Punisher's story arcs of the 1980s even expanded upon these cynical themes. In the mini-series The Punisher \#1 (1985), the Punisher is sent to jail for his brutal crime-fighting methods. The jail is presented as a symbol of democratic and reformist impulses. Its values are systemically destroyed when the Punisher asserts his will over the prisoners. ${ }^{231}$ He kills inmates who try to brazenly assert their authority. Incarceration is another opportunity to fight crime. The jail is the ideal representation of a corrupt American society. The Punisher series suggests that corruption stems from the political climate of the 1980s.

\footnotetext{
${ }^{226}$ Mike W. Barr et al., Captain America no. 241, Essential Punisher Vol. 1 (New York: Marvel Comics Ltd., 2004), 12.

${ }^{227}$ Archie Goodwin et al., Marvel Super Action Featuring the Punisher: America's Greatest Crime Destroyer!, Essential Punisher Vol. 1 (New York: Marvel Comics Ltd., 2004), 1.

${ }^{228}$ Ryan Moore, “...And Tomorrow Is Just Another Crazy Scam”: Postmodernity, Youth, and the Downward Mobility of the Middle Class," in Generations of Youth: Youth Cultures and History in Twentieth-Century America, ed. Joe Austin and Michael Nevin Willard (New York: New York University Press, 1998), 254.

${ }^{229}$ Ibid., 257.

${ }^{230}$ Moore, “...And Tomorrow Is Just Another Crazy Scam,” 254.

${ }^{231}$ Steven Grant et al., The Punisher: Circle of Blood no. 1, Essential Punisher Vol. 1 (New York Marvel Comics, Ltd., 2004, 3.
} 
The political values embraced by mainstream American society in the 1980s were at odds with a rebellious youth culture. Superheroes would side with youth culture often becoming meta-textual in references to 1980s American culture. As an idealized model of an apathetic youth mindset during the 1980s, the Punisher shows us the end result of the changes in the superhero medium. Nevertheless, he can not explain the evolutionary process of superhero archetypes since he is a product of the epoch. The blind superhero Daredevil exemplified the gap between 1960s principled idealism and the 1980s dystopia of violence and corruption.

Daredevil was created in 1964 and reflected many of the attributes of his superhero peers. His acrobatic prowess and mocking banter with villains took its influence from the popular Spider-Man model. Daredevil's alter ego, Matt Murdock, depended upon formulaic plot devices to attract readers. In one early story, Murdock invented and posed as his own twin brother, Mike Murdock, in order to get closer to the lovely Karen Page. ${ }^{232}$ However, Daredevil remained a niche title with only limited signs of growth as the 1980s began. The problem was that Daredevil's futile pursuit for love was no longer applicable to teenagers. The dating and courtship rituals for youth had markedly changed since the 1960s. Dating in the public sphere had won out among youth. An open and liberalized view of sexuality and gender "had been rendered safe - knowable, and thus unthreatening." ${ }^{233}$ Daredevil needed to evolve in order to provoke interest among teenagers.

Frank Miller was given the job of reviving interest in Daredevil in 1979. Miller was a promoter of a "noir" style of writing. His artistic rendition of Daredevil's world was gritty and dark. Miller's writing style matched the new artistic direction by being lean and concise. Furthermore, Miller removed the campy and formulaic elements that Daredevil had relied upon ever since its publication. In place of commonplace crime-fighting, Miller put Daredevil in exigent situations with no obvious solutions. A frequent element that was introduced by Miller in order to sustain Daredevil's conflict was the Christian faith. Daredevil represents the trend of conforming to an individualistic "conception of religious faith.,"234

The 1980s saw a revitalization of evangelical Christianity. Faith was seen as a comforting notion in the face of perceived corporate corruption and violent urban streets. Congregations turned to charismatic leaders with discernible solutions to youth society's ills. Pat Robertson and Jerry Falwell used their influence as leaders of the Christian community to form powerful coalitions on political issues that affected youth. Increasingly, church membership "encouraged the congregation to be passive."235 As a superhero, the onus on solving society's problems was clearly with Daredevil. The society he protected

${ }^{232}$ Stan Lee et al., Marvel Masterworks: Daredevil Vol. 3 (New York, Marvel Entertainment Group, 2005), 80.

${ }^{233}$ Bailey, From Front Porch to Back Seat, 2.

${ }^{234}$ Tom Morris, "God, the Devil, and Matt Murdock," in Superheroes and Philosophy: Truth, Justice, and the Socratic Way, ed. Tom Morris and Matt Morris (Chicago: Open Court, 2005), 57.

${ }^{235}$ Michael Kammen, American Culture, American Tastes: Social Change and the Twentieth Century (New York: Basic Books, 1999), 88. 
depended on him to make the moral choice of defending them against the criminal element. In effect, Daredevil serves as a proto-messiah for his audience. Daredevil's collection of supervillains was culled from the dystopia of the 1980s. In particular, Daredevil's most dangerous adversary was the mob boss, Kingpin. Miller's story arc "Born Again" (Daredevil \#227-233, 1986) serves as a reaffirmation of Daredevil's Christian faith and the fallibility of corrupt institutions. "Born Again" can be seen as an evangelical discourse pitting the Christ-like figure Daredevil against the Satanic Kingpin.

In "Born Again," we see Daredevil confront the knowledge that the Kingpin has discovered his secret identity. Daredevil's relative Eden is ruined by the profit motive of 1980s business tycoons. Everyone has a price, even Daredevil's supposed allies. Karen Page gives up Daredevil's real identity because she needs a drug fix. ${ }^{236}$ The Kingpin thrives in this corrupted environment. He seems to have the financial and legal institutions of New York City paid off to look the other way. Miller pits corporatism against Daredevil's moral ideals of honesty and heroism. Thus, big business assumes an inherently sinister designation for Miller. Youth culture saw these trends as antithetical to democratic institutions.

The redemption of Daredevil in "Born Again" offered "recurrent traces of promise in the realm" of youth culture. ${ }^{237}$ Even though Daredevil takes matters into his own hands, he reaffirms the values of personal autonomy and democracy. The insertion of Nuke, a former Vietnam War soldier, into "Born Again" reveals that popular democracy is in danger of being replaced by Kingpin's mob rule. The fact that Nuke is corrupted by the Kingpin into attacking Daredevil shows the general fragility of liberalism during the 1980s. Youth culture during the 1980s grew up under the influence of the Reagan Revolution. Nuke is a parable for youthful idealism. The Kingpin states to Nuke, "I am not a villain, my son. I am a conglomerate that is America."238 Miller effectively twists business's evil tendencies into patriotic motives for Nuke. Free enterprise is the most important American practice to protect, according to the Kingpin. The Kingpin has managed to prove he can sell out youthful idealism through the character of Nuke. Daredevil must combat "the passive dissent" of the 1980s and restore his past notions of heroism. ${ }^{239}$ Miller uses "Born Again" as an argument that faith and democratic institutions can not coexist with the widespread corruption of American society in the 1980s.

The graphic novels The Dark Knight Returns (1986) by Frank Miller and Watchmen (1986-87) by Alan Moore represent the youth national mood as it existed during the 1980s. Miller and Moore's works expressed the sufferings "from illusions, imbalances, and dogma" of the epoch despite an increasing tolerance of diversity and awareness of civil liberties. ${ }^{240}$ Previously, the

\footnotetext{
${ }^{236}$ Frank Miller et al., Daredevil: Born Again (New York: Marvel Entertainment Group, 2005), 5.

237 John Shelton Lawrence and Robert Jewett, The Myth of the American Superhero (Grand Rapids: William B. Eerdmans Publishing Co., 2002), 351.

${ }^{238}$ Miller, Daredevil: Born Again, 138.

${ }^{239}$ Kammen, American Culture, American Tastes, 212.

${ }^{240}$ Stephen J. Whitfield, The Culture of the Cold War (Baltimore: Johns Hopkins University Press, 1991), 229.
} 
superhero narrative had valued a formulaic archetype. The superhero was noble, morally right, and a strong role model. Miller and Moore deconstructed these themes in order to rationalize a new cultural order and to "rework characters with a fifty-year history."241 Elements of the human condition were reevaluated through satire and characterization. Determinism, fascism, and American cultural concepts such as hero worship were critically analyzed by Miller and Moore. By revising the superhero narrative, Miller and Moore's works revealed the disdain of youth culture for their future adulthood. The heavy revisionism present in both works demonstrated a permanent shift in the marketing of superheroes as well as an end to the legacy of the Silver Age of comics.

The Dark Knight Returns is a Batman tale set in the future. Batman has been retired for ten years and his alter ego, Bruce Wayne, is in his late fifties. A new gang calling themselves the Mutants has terrorized Gotham City into an unprecedented era of urban decay and corruption. Bruce Wayne yearns to take up the mantle of the bat once more in order to set things right. Images of a "golden age" of crime-fighting gnaw at Wayne's conscience. ${ }^{242}$ The concept of the proto-messiah is once again invoked when Wayne reappears as Batman. Only the Batman can save Gotham from self-imposed destruction. The Gotham City police force has proven itself to be incompetent and corrupt. The U.S. government, with a caricatured Ronald Reagan, has instituted a police state which has no room for independent vigilantes. ${ }^{243}$

The setting of The Dark Knight Returns is a satirized portrayal of the American 1980s political and cultural environment. Miller invokes realism by placing a clear analogue for President Reagan. In addition, the use of TV talking heads in various panels mirrors the rise of cable network news in the 1980s. ${ }^{244}$ We are meant to see a dystopian vision of 1980s America in the graphic novel. The end of the Cold War is near in Batman's world. In an era of conservative revival, Batman must use his own version of justice in order to succeed against his opponents. His crime-fighting methods are strikingly similar to the superhero archetype popularized by the Punisher. In order to defeat his arch-nemesis, the Joker, Batman partially paralyzes him. ${ }^{245}$ The political themes reveal an attempt by Miller to add layers of cultural and historical meaning to the superhero narrative. The Dark Knight Returns functions as something more than standard superhero fare. In fact, Miller's portrayal of Batman is so mature and hyperrealistic that he is almost unrecognizable from the campy Batman of the 1960s.

Satire is invoked by Miller throughout The Dark Knight Returns. The satire serves as social commentary on the political ideology of the 1980s. The most effective target of satirical means is Superman. As an agent of the federal government, Superman is obliged to physically confront Batman's unwanted crusade on crime. Batman mocks Superman's stance, proclaiming “you always

${ }^{241}$ Will Brooker, Batman Unmasked: Analyzing A Cultural Icon (New York: Continuum Publishing Group, 2001), 262.

${ }^{242}$ Frank Miller et al., The Dark Knight Returns (New York: DC Comics, 2002), 21-24.

${ }^{243}$ Ibid., 84.

${ }^{244}$ Ibid., $10-1$.

${ }^{245}$ Ibid., 150. 
say yes-- to anyone with a badge-- or a flag."246 Superman's moral values are being subjugated and exploited in the eyes of Batman. Batman favors a form of superhero rule rather than the government. He declares, "the world only makes sense when you force it to.”247 Miller places him into the role of a sympathetic revolutionary. This decision enables Batman to adopt a liberal righteousness in his goals for Gotham City and America.

Miller has gone on to reveal other satiric caricatures in The Dark Knight Returns. The Mutant gang dialect "was taken almost word-for-word from a suburban white dialect.”248 Suburbia is being critically analyzed by Miller. The threat to racial and sexual homogeneity in suburbia was a driving force for the political rhetoric of the 1980s. During the 1980s, figures estimated that the number of children "living in poverty increased by 2.2 million." 249 As a gang of youthful misfits, the Mutants are a large but oppressed minority group. Their unified disaffection of American culture threatens the social fabric of Gotham City. This created distinct cultural tropes of 1980s white suburbia that was seen as being a danger to mainstream American society.

Alan Moore's Watchmen is also set in a Cold War timeframe mirroring the 1980s. Unlike The Dark Knight Returns, however, Moore's Watchmen does not have a worthy goal for the protagonists to achieve. Even the superheroes are cloaked in moral ambiguity. The story begins with a "golden-age" hero being brutally killed by an unknown assailant. The surviving superheroes must figure out who is behind these attacks as well as avoid political entanglements with an U.S. government embroiled in a nuclear standoff with the Soviet Union. Each of the superheroes we meet in Watchmen is based on a specific superhero archetype. For example, the character of Rorschach is built upon the moral values of vigilantes such as the Punisher. Dr. Manhattan and Ozymandias are deified in line with the Golden Age versions of Superman and Hawkman respectively. In fact, most of the heroes are failed and flawed remnants of the Golden Age. Nite Owl II cannot perform sexually if he is not in costume. ${ }^{250}$

The ending epitaph "who watches the watchmen?" invokes the charged political atmosphere of the 1980s as well as casting doubt on the nature of heroism. $^{251}$ Moore's cynicism towards the evolution of superheroes can also be seen as a critique on youth. His reasoning focuses on the new violent vigilantes produced during the 1980s. The youth market accepts these vigilantes as true heroes. Moore does not. He argued that the more innocent "Golden Age" superhero archetypes fostered sincere efforts at heroism. The subtle irony of

\footnotetext{
${ }^{246}$ Frank Miller et al., The Dark Knight Returns (New York: DC Comics, 2002), 190.

${ }^{247}$ Ibid., 192.

248 Christopher Sharrett, "Batman and the Twilight of the Idols: An Interview with Frank Miller" in The Many Lives of Batman: Critical Approaches to a Superhero and His Media, ed. Roberta E. Pearson and William Uricchio (New York: Routledge, 1991), 38.

${ }^{249}$ George Lipsitz, “The Hip Hop Hearings: Censorship, Social Memory, and Intergenerational Tensions Among African Americans in Generations of Youth: Youth Cultures and History in Twentieth Century America (New York: New York University Press, 1998), 397.

${ }^{250}$ Alan Moore and Dave Gibbons, “Chapter VII,” Watchmen (New York: DC Comics, 1987), 167.

${ }^{251}$ Alan Moore and Dave Gibbons, “Chapter XII,” Watchmen (New York: DC Comics, 1987), 34.
} 
Moore's Watchmen is that he uses the apocalyptic tropes popular during the 1980s in order to prove his point. For example, Nite Owl II remarks, "it's all crap dressed up with a lot of flash and thunder." 252 The comic book audience has become too grown up to delight in tales of colorful draped superheroes fighting against masked villains. Moore devalues "one of the basic superhero conventions" that he felt was important to the vitality of the "Golden Age" and youth culture. ${ }^{253}$ The innocence of youth is permanently broken in Moore's opinion. The Cold War allegory of Watchmen passes judgment on youth culture. The supervillain of the tale, Ozymandias, seeks to remedy the political crisis by eliminating a large portion of the U.S. population. The U.S. citizens are another trope, representing the grown up youth culture of the 1980s. Ozymandias's previous status as a god-like Golden Age archetype is tainted by the betrayal of his youth audience.

Final judgment is passed when Ozymandias personally decides to commit massive genocide in New York City. The apocalyptic vision, only explored in The Dark Knight Returns, is brought to vivid fruition by Moore and artist Dave Gibbons. ${ }^{254}$ The rest of the superheroes are powerless to stop Ozymandias. They are forced to bear the knowledge of what Ozymandias has done but not expose him publicly. ${ }^{255}$ The only hero to challenge Ozymandias is Rorschach. The more violent and youthful vigilante must challenge the older and revered superhero. Rorschach's moral compass may be in the right place; however, his status as a 1980s vigilante gets him killed. ${ }^{256}$ The nihilism of Watchmen signals the death of "everyday heroism" promoted by youth culture up until the 1980s. ${ }^{257}$ Moore and Miller's graphic novels are a testament to the evolutionary changes brought forth in the superhero narrative. Youth culture had embraced the anti-hero due to the innovations of the direct market, American political developments, and their growing sense of old age. The last vestiges of the Golden and Silver Ages of superheroes went out in a blaze of violence and apathy.

\section{Conclusion}

Superhero narratives have always been at the forefront of American cultural history. The interweaving of historical themes and fantasy elements has proven to be an irresistible combination for comic book readers into the present day. Starting in the Great Depression, enduring characters such as Superman laid down the roots of the liberal superhero tradition. World War II saw the superhero reach unprecedented heights in popularity and notoriety. The beginning of the Cold War during the 1950s saw a backlash against superheroes led by the irascible Dr. Fredric Wertham. The resulting CMAA code placed extremely

\footnotetext{
${ }^{252}$ Moore and Gibbons, “Chapter VII,” 8.

${ }^{253}$ Geoff Klock, How to Read Superhero Comics and Why (New York: Continuum, 2002), 63.

${ }^{254}$ Moore and Gibbons, “Chapter XII,” 1-3.

${ }^{255}$ Ibid., 20.

${ }^{256}$ Ibid., 23-4.

257 Jay Mechling "Heroism and the Problem of Impulsiveness for Early Twentieth-Century American Youth" in Generations of Youth: Youth Cultures and History in Twentieth Century America (New York: New York University Press, 1998), 44.
} 
conservative restrictions on what could be depicted on the pages of a typical superhero comic book. However, the 1960s saw a gradual rebirth of the superhero narrative following the emergent success of Marvel Comics and their new character archetypes. The continuation of the Cold War provided superhero narratives with an increasing ambiguity and anxiety about America's future. These themes would continue to percolate into the 1970s. Established superheroes such as Batman began to evolve with the changing political and cultural environment. The end of the Cold War in the 1980s signaled another drastic change for the superhero narrative. Structural changes such as the emergence of the graphic novel and the direct market morphed superheroes into a youth subculture. The political implications of the end of the Cold War brought even more anxiety about America's new role as the only superpower in the world. Superhero narratives would come to embrace the anti-hero and a vast deconstruction of the superhero's roots defined during the Great Depression. Despite the myriad changes outlined, the superhero has always reflected the national mood of American society, particularly its youth.

The arguments outlined in this essay do not stop in the 1980s. The global war on terror has provided new historical opportunities for superheroes to explore. Following the events of September 11, 2001, superheroes such as Captain America and Spider-Man confronted the tragedy head-on in their monthly titles. J. Michael Straczynski, writer of Amazing Spider-Man, explained this direction succinctly: “Kids don't stay up till 11:30 to watch 'Nightline,'...You need something they are going to read to explain [it]."258 Even more ambitiously, mini-series such as Marvel's Civil War (2006-2007) has become direct allegories of the Iraq War and a fascinating critique on the debate over the erosion of American civil liberties. Most recently, large media attention was given to the death of Captain America and the “American Dream” in Captain America \#25 (2007). The cultural contribution of superheroes to mainstream American society continues despite its presumed status as an amateur pursuit for young fanboys.

Sebastian T. Mercier graduated in 2007 from the University of Iowa with honors in history. He is currently enrolled in the M.A. program at Rutgers University studying American History. His research interests range from American popular culture to Native American studies. He hopes to pursue a career as a writer after school.

${ }^{258}$ Raoul V. Mowatt, "Superheroes to the Rescue: Comic Books try to draw conclusions about Sept. 11 attacks,” Chicago Tribune 30 November 2001, Midwest edition, p. 3. 